Portland State University

PDXScholar

Environmental Science and Management

Faculty Publications and Presentations

$1-2012$

\title{
Greenhouse Gas Fluxes in Southeastern U.S. Coastal Plain Wetlands Under Contrasting Land Uses
}

\author{
Jennifer L. Morse \\ Portland State University, jlmorse@pdx.edu \\ Marcelo Ardón \\ Duke University \\ Emily S. Bernhardt \\ Duke University
}

Follow this and additional works at: https://pdxscholar.library.pdx.edu/esm_fac

Part of the Environmental Monitoring Commons, Oceanography and Atmospheric Sciences and Meteorology Commons, and the Terrestrial and Aquatic Ecology Commons Let us know how access to this document benefits you.

\section{Citation Details}

Jennifer L. Morse, Marcelo Ardón, and Emily S. Bernhardt 2012. Greenhouse gas fluxes in southeastern U.S. coastal plain wetlands under contrasting land uses. Ecological Applications 22:264-280. http://dx.doi.org/10.1890/11-0527.1

This Article is brought to you for free and open access. It has been accepted for inclusion in Environmental Science and Management Faculty Publications and Presentations by an authorized administrator of PDXScholar. Please contact us if we can make this document more accessible: pdxscholar@pdx.edu. 


\title{
Greenhouse gas fluxes in southeastern U.S. coastal plain wetlands under contrasting land uses
}

\author{
Jennifer L. Morse, ${ }^{1}$ Marcelo Ardón, ${ }^{2}$ And Emily S. Bernhardt \\ Department of Biology, Box 90338, Duke University, Durham, North Carolina 27708 USA
}

\begin{abstract}
Whether through sea level rise or wetland restoration, agricultural soils in coastal areas will be inundated at increasing rates, renewing connections to sensitive surface waters and raising critical questions about environmental trade-offs. Wetland restoration is often implemented in agricultural catchments to improve water quality through nutrient removal. Yet flooding of soils can also increase production of the greenhouse gases nitrous oxide and methane, representing a potential environmental trade-off. Our study aimed to quantify and compare greenhouse gas emissions from unmanaged and restored forested wetlands, as well as actively managed agricultural fields within the North Carolina coastal plain, USA. In sampling conducted once every two months over a two-year comparative study, we found that soil carbon dioxide flux (range: 8000-64 $800 \mathrm{~kg} \mathrm{CO} \cdot \mathrm{Ca}^{-1} \cdot \mathrm{yr}^{-1}$ ) comprised $66-100 \%$ of total greenhouse gas emissions from all sites and that methane emissions (range: -6.87 to $197 \mathrm{~kg} \mathrm{CH}_{4} \cdot \mathrm{ha}^{-1} \cdot \mathrm{yr}^{-1}$ ) were highest from permanently inundated sites, while nitrous oxide fluxes (range: -1.07 to $139 \mathrm{~kg} \mathrm{~N} \mathrm{~N}_{2} \mathrm{O} \cdot \mathrm{ha}^{-1} \cdot \mathrm{yr}^{-1}$ ) were highest in sites with lower water tables. Contrary to predictions, greenhouse gas fluxes (as $\mathrm{CO}_{2}$ equivalents) from the restored wetland were lower than from either agricultural fields or unmanaged forested wetlands. In these acidic coastal freshwater ecosystems, the conversion of agricultural fields to flooded young forested wetlands did not result in increases in greenhouse gas emissions.
\end{abstract}

Key words: carbon dioxide; denitrification; greenhouse gas; methane; nitrous oxide; North Carolina coastal plain; restoration; soil respiration; wetland.

\section{INTRODUCTION}

The extent of wetlands worldwide has been diminished by $\sim 50 \%$ through human activities such as clearing, filling, ditching, and drainage (Millennium Ecosystem Assessment 2005). In the United States, the majority of wetland conversions occurred from the 1780 s through 1980 , primarily driven by agricultural expansion (Dahl 1990). About $27 \%$ of active U.S. farmland occurs on former wetland soils (Heimlich et al. 1998, Natural Resources Conservation Service 1999), and this pattern is also seen in many regions of the world (Zedler 2003). In North Carolina, $13 \%$ of the state's wetlands were drained and converted to agriculture between 1970 and 1980, particularly in the coastal plain (Dahl 1990, Heimlich et al. 1998). The loss of wetlands has impaired wetland ecosystem services, including wildlife habitat, protection from flooding, carbon (C) storage, and water quality benefits (Zedler and Kercher 2005). On regional and local scales, decreased wetland area and the resulting decreased capacity to retain

Manuscript received 21 March 2011; revised 26 July 2011; accepted 29 July 2011. Corresponding Editor: K. K. Treseder.

${ }^{1}$ Present address: Cary Institute of Ecosystem Studies, Box AB, 2801 Sharon Turnpike, Millbrook, New York 12545 USA. E-mail: morsej@caryinstitute.org

2 Present address: Department of Biology, East Carolina University, Greenville, North Carolina 27858 USA. nutrients in watersheds, along with increased agricultural fertilizer use, contribute to coastal eutrophication and hypoxia (Rönnberg and Bonsdorff 2004, Mitsch et al. 2005, Turner et al. 2008).

The 1989 U.S. policy known as "no net loss" promotes compensatory mitigation to offset future wetland losses through wetland restoration or creation (National Research Council 2001). Wetland restoration efforts are intended to replace habitat and improve water quality (Mitsch 2005, Verhoeven et al. 2006). Marginally productive agricultural areas in former wetlands are often candidates for restoration because of their landscape position, residual organic soils, and poorly drained status, and because economic incentives may exist to promote wetland restoration (Heimlich et al. 1998, Zedler 2003). Restoring forested wetlands in the Mississippi Alluvial Valley can provide net economic benefits to landowners, through governmental Wetlands Reserve Program payments, and to society based on the valuation of ecosystem services provided by the restored wetlands (Jenkins et al. 2010).

Wetland restoration practices in agricultural landscapes generally aim to restore ecosystem functions by re-establishing wetland hydrology and vegetation by recontouring fields, filling ditches, reconnecting wetland areas to surface waters, and planting obligate and facultative wetland species (Zedler and Kercher 2005). Quantification of ecosystem function resulting from 
restoration is rarely required or attempted; proxies such as survival of planted trees and mean growing season water table depth (WTD) based on reference wetlands generally are the most commonly mandated metrics for evaluating wetland restoration (e.g., Brinson and Rheinhardt 1996, U.S. Army Corps of Engineers 1997). While wetland restoration ecology aims to predict restoration outcomes and trajectories for multiple ecosystem services (Zedler and Callaway 1999, Zedler 2000), in restoration practice, specific functional goals are rarely set, and the possibility that some ecosystem services may be promoted at the expense of others is seldom addressed (Jackson et al. 2005, Zedler and Kercher 2005). For example, the same conditions that promote nutrient removal from polluted waters may suppress biodiversity or increase greenhouse gas (GHG) emissions (Verhoeven et al. 2006, Wilcock et al. 2008). These potential trade-offs need to be identified and evaluated, so that they can be incorporated into environmental policies, if warranted.

Nutrient removal by wetlands from surface and subsurface waters through sediment deposition, organic matter accumulation, adsorption to particles, and biological uptake is well documented (Richardson 1985, Seitzinger 1988, Johnston 1991). For nitrogen $(\mathrm{N})$, microbial denitrification (DNF) is the main mechanism of permanent removal, as it converts nitrate $\left(\mathrm{NO}_{3}{ }^{-}\right)$to gaseous $\mathrm{N}$ (dinitrogen: $\mathrm{N}_{2}$ or nitrous oxide $\left[\mathrm{N}_{2} \mathrm{O}\right]$ ). Because it is an anaerobic heterotrophic process, DNF may be stimulated during transient wet events, such as rainstorms (Poe et al. 2003), or when wetlands are restored by re-flooding, if sufficient $\mathrm{NO}_{3}{ }^{-}$and labile $\mathrm{C}$ are available. It follows that when agricultural wetlands are restored, the cessation of fertilizer inputs and facilitated drainage, coupled with enhanced DNF, could result in lower hydrologic exports of reactive $\mathrm{N}$ (Verhoeven et al. 2006, Orr et al. 2007).

Promoting enhanced DNF is not an unequivocal environmental benefit (Schlesinger et al. 2006), since under incomplete anoxia or high $\mathrm{NO}_{3}{ }^{-}$availability, DNF can produce $\mathrm{N}_{2} \mathrm{O}$ (Davidson et al. 2000), which is a stratospheric ozone-depleting gas with 298 times the global warming potential of carbon dioxide $\left(\mathrm{CO}_{2}\right.$, Forster et al. 2007). Agricultural lands, through $\mathrm{N}$ fertilization and soil emissions, are currently the largest source of $\mathrm{N}_{2} \mathrm{O}$ to the atmosphere (Mosier et al. 1998). Although undisturbed wetlands have not been shown to be major sources of $\mathrm{N}_{2} \mathrm{O}$ globally (Bridgham et al. 2006), there are significant concerns that wetland restoration, by combining wetland hydrology with ongoing agricultural $\mathrm{N}$ inputs or legacy fertilizer $\mathrm{N}$, could enhance DNF and promote $\mathrm{N}_{2} \mathrm{O}$ emissions in agricultural restored wetlands (Verhoeven et al. 2006).

Furthermore, the same flooded soils that promote DNF may also increase the production of methane $\left(\mathrm{CH}_{4}\right)$, the $\mathrm{GHG}$ with the greatest radiative forcing after $\mathrm{CO}_{2}$. Emissions from wetlands represent $15-40 \%$ of global $\mathrm{CH}_{4}$ fluxes (Bridgham et al. 2006, Forster et al.
2007). Methane (global warming potential $=25 \times \mathrm{CO}_{2}$ ) is produced by methanogenic microbes in highly reduced soils or in anoxic microsites and is consumed by methanotrophic microbes in oxic environments. Flooded soils tend to have lower rates of soil respiration, and thus, lower $\mathrm{CO}_{2}$ emissions from wetland soils could partially offset the increased production of $\mathrm{N}_{2} \mathrm{O}$ and $\mathrm{CH}_{4}$ trace gases (Raich and Schlesinger 1992, Whiting and Chanton 2001).

Our study was designed to evaluate the effect of wetland restoration on multiple ecosystem services in a 440-ha former agricultural field in coastal North Carolina, USA. Our primary objective was to compare the composition and magnitude of $\mathrm{GHG}$ fluxes $\left(\mathrm{CO}_{2}\right.$, $\mathrm{N}_{2} \mathrm{O}$, and $\mathrm{CH}_{4}$ ) throughout the restored wetland with GHG fluxes from adjacent agricultural fields and undrained forested wetlands. Our second objective was to examine whether variation in hydrology across this very large restored wetland led to predictable changes in GHG fluxes. We sampled gas fluxes from 48 permanent sampling stations across the four sites once every two months from July 2007 to June 2009. We hypothesized that hydrologic setting would determine GHG fluxes both within and across the land use types, such that (1) in drier sites, GHG fluxes would be low and dominated by $\mathrm{CO}_{2} ;$ (2) in sites with intermittently flooded conditions, nutrients would cycle more rapidly, thus producing more $\mathrm{CO}_{2}$ and $\mathrm{N}_{2} \mathrm{O}$; and (3) in sites with more permanently flooded conditions, $\mathrm{CH}_{4}$ would be the dominant GHG. We expected that fertilizer and legacy $\mathrm{N}$ would both enhance $\mathrm{N}_{2} \mathrm{O}$ fluxes, such that (4) in the agricultural site, $\mathrm{N}_{2} \mathrm{O}$ fluxes would be associated with fertilization; (5) that the restored wetland would have the highest annual fluxes of $\mathrm{N}_{2} \mathrm{O}$ as a result of legacy fertilizer $\mathrm{N}$ and re-flooded conditions; and (6) that forested wetlands would have the highest fluxes of $\mathrm{CH}_{4}$, based on their relatively undisturbed hydrology, organic soils, and low $\mathrm{N}$ inputs.

\section{Methods \\ Geographic setting and history}

Our study sites are located in the Albemarle Peninsula, in the Outer Coastal Plain of North Carolina, USA (Fig. 1). There is little topographic relief, with $>54 \%$ of the $5000-\mathrm{km}^{2}$ peninsula under $1 \mathrm{~m}$ elevation (Poulter and Halpin 2008). The Albemarle Peninsula is bounded by the Albemarle, Croatan, and Pamlico Sounds. The climate is classified as humid-subtropical, with mean annual precipitation of $1330 \mathrm{~mm} / \mathrm{yr}$ and temperature of $16.6^{\circ} \mathrm{C}$ (State Climate Office, Raleigh, North Carolina, USA). Hydrology in this low-relief basin is driven by precipitation, evapotranspiration, and wind tides (Richardson and McCarthy 1994).

The region was historically dominated by pocosin wetlands, with deep Histosol soils, pine forests, and an understory of evergreen shrub-scrub vegetation (Richardson 2003), as well as swamp forests along blackwater creeks. Much of the landscape was logged in the 19th 

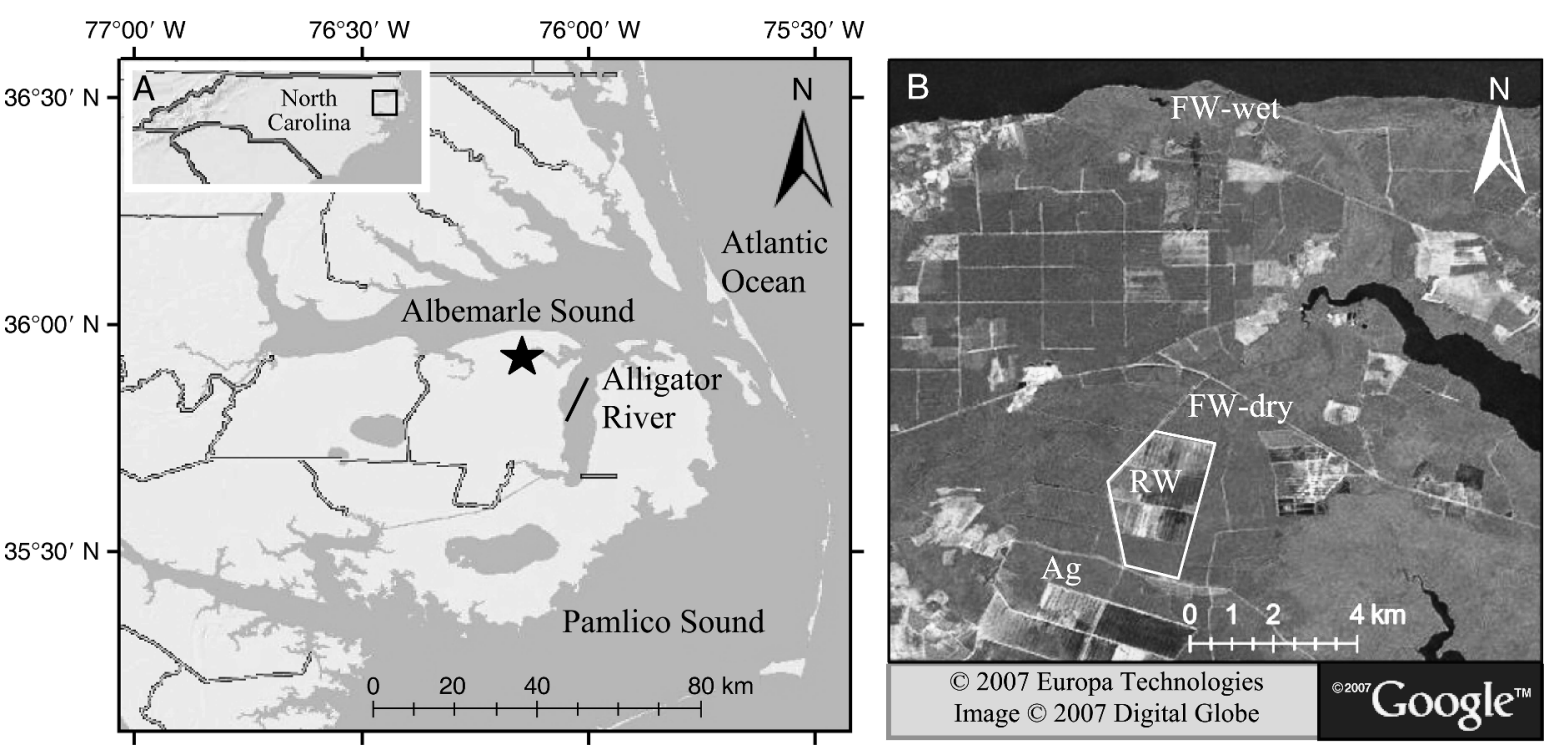

FIG. 1. Geographic location of the study in North Carolina, USA: (A) overview (with the star indicating the area of the sampling sites) and (B) detailed view of the four sampling sites (agricultural field [Ag], restored wetland [RW], forested wetland in Timberlake Restoration Project preservation area [FW-dry], and Palmetto Peartree Preserve reference forested wetland [FW-wet]). The figure is adapted from Ardón et al. (2010b). Panel B was created using Google Earth under the fair use policy; images and data are copyrighted by Europa Technologies, Digital Globe, and Google (2007).

and 20th centuries; large-scale conversion to agriculture occurred in the 1970-1980s with the construction of large canals and drainage systems (Carter 1975). By 1979 , only $9 \%$ of historical pocosins remained in the North Carolina coastal plain (Richardson 1983). Much of the Albemarle Peninsula is currently in agriculture (corn-soybean row crops), of which $80 \%$ requires active drainage to maintain arable fields (Neely 2008).

\section{Site descriptions}

The primary study location is a large compensatory

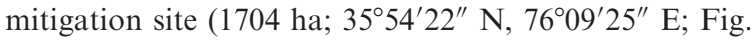
1), known as the Timberlake Restoration Project (TLRP) and owned by Great Dismal Swamp Mitigation Bank (Chesapeake, Virginia, USA). TLRP drains to the Little Alligator River, which flows into the Alligator River and Albemarle Sound. The elevation in TLRP ranges from $-1 \mathrm{~m}$ to $2 \mathrm{~m}$ above sea level (lidar survey by National Center for Airborne Laser Mapping 2008, Houston, Texas, USA). The TLRP property historically was the headwaters for coastal blackwater streams, with pocosin vegetation in higher elevation areas (Needham 2006). Swamp forests in the site were cleared, drained, and converted to agriculture in the 1970s, while some areas remained forested. The TLRP property currently contains drained shrub-scrub wetlands, restored and selectively timbered forested wetlands, and former agricultural fields undergoing stream and wetland restoration. The former corn and soybean farmland within TLRP (440 ha), last harvested in 2004, is the restored wetland (RW) that is the focus of our study. Restoration of the TLRP agricultural area towards a forested wetland was initiated in 2004 by lowering the field crowns and filling drainage ditches and then planting 750000 live saplings. Obligate and facultative wetland tree species were planted, including Taxodium distichum, Nyssa sylvatica, Nyssa aquatica, Fraxinus pennsylvanica, Salix nigra, Chamaecyparis thyoides, Quercus nigra, Quercus michauxii, Quercus phellos, and Quercus falcata var pagodifolia (Table 1). In 2007 the former fields were hydrologically connected to both the upstream forest and downstream waters. The two dominant soil series in the RW are very poorly drained hydric soils: Ponzer muck (loamy, mixed, dysic, thermic Terric Haplosaprist) and Hyde loam (fine-silty, mixed, active, thermic Typic Umbraquult; Natural Resources Conservation Service 2009). The site and the restoration practices have been described in detail by Ardón et al. (2010a, b).

The agricultural site (Ag), cropped in a corn and soybean rotation (Table 1 ), is immediately adjacent to RW and is drained by a system of ditches and pumps, part of which discharges into $\mathrm{RW}$. It is mainly comprised of Weeksville silt loam soils (coarse-silty, mixed, semiactive, thermic Typic Umbraquult; Natural Resources Conservation Service 2009). One of the reference sites is a preservation area ( $F W$-dry) that was established in a minimally impacted forested wetland portion of TLRP, dominated by a mixed hardwood forest (oak-tupelo-cypress; Table 1; Needham 2006). The soils in FW-dry are mapped as Dorovan muck (dysic, thermic Typic Haplosaprist; Natural Resources Conservation Service 2009). The other reference site (FW-wet) is located $8 \mathrm{~km}$ away in the Palmetto Peartree Preserve (Fig. 1B), in a swamp hardwood stand of cypress and tupelo (Table 1). Soils 
in FW-wet are mapped as Belhaven muck (loamy, mixed, dysic, thermic Terric Haplosaprist; Natural Resources Conservation Service 2009).

\section{Sampling locations}

Just prior to hydrologic restoration in 2007, we established two transects with 33 sampling points to capture the expected extent of the flooding gradient. We set up sampling locations $(n=5)$ within each of the three reference sites. At each sampling location, we excavated a soil profile to $50 \mathrm{~cm}$ depth, measuring the thickness of the surface organic horizon (where present) and the depth to the relatively impermeable mineral horizon below (except in the Ag site, where we were only able to auger to $15 \mathrm{~cm}$ due to soil compaction). We defined our system boundaries as the surface horizon above the mineral confining layer; in all sites, depth to this mineral horizon was at least $15 \mathrm{~cm}$, and was well over $50 \mathrm{~cm}$ in the reference forested wetlands.

\section{Environmental variables}

Each sampling location was instrumented with five platinum-tipped redox electrodes (Vepraskas and Faulkner 2001). To monitor near-surface and surface waters, we installed slotted polyvinyl chloride (PVC) monitoring wells to just above the mineral horizon layer (or to $45 \mathrm{~cm}$ depth, where the mineral horizon was deeper than 45 $\mathrm{cm}$ ), and programmed a water level recorder (Levelogger Gold or Silver, Solinst Instruments, Ontario, Canada) in each well to record pressure and temperature every $15 \mathrm{~min}$. The slots extended to $10 \mathrm{~cm}$ above the ground surface, allowing the Leveloggers to register the pressure of overlying water even when the water table was above the ground surface. Well positions and elevations were professionally surveyed by R. Sanderson (Geodetic Services, Virginia Beach, Virginia, USA) in 2008.

At each sampling location, we collected soil samples from $0-15 \mathrm{~cm}$ to determine soil characteristics, including organic carbon content, $\mathrm{pH}$, soil texture, and bulk density. We used a $5 \mathrm{~cm}$ diameter soil sampler with a slide hammer attachment (AMS, American Falls, Idaho, USA) for bulk density (BD) sampling without significant compaction in $\mathrm{Ag}$ and RW sites. Compaction was a problem in the FW sites; to collect intact samples, we sharpened $10 \mathrm{~cm}$ diameter PVC cylinders, pushed them into the soil, and carefully dug around them to remove them. Soil organic $\mathrm{C}$ content was determined with a Carlo Erba Elemental Analyzer (Carlo Erba, Milano, Italy). Soil $\mathrm{pH}$ was measured on replicate 3 -g samples in $5 \mathrm{~mL}$ of $0.01 \mathrm{~mol} / \mathrm{L} \mathrm{CaCl}_{2}$, which is preferable to water when soils have high C content (Hendershot et al. 1993). We extracted inorganic $\mathrm{N}$ from duplicate $2.5 \mathrm{-g}$ soil samples with $25 \mathrm{~mL}$ of $2 \mathrm{~mol} / \mathrm{L} \mathrm{KCl}$, and analyzed the extracts for $\mathrm{NH}_{4}^{+}$and $\mathrm{NO}_{3}^{-}$on a Lachat QuickChem 8000 automated system using the phenate method for $\mathrm{NH}_{4}{ }^{+}$and the hydrazine reduction method for $\mathrm{NO}_{2}{ }^{-}+$
$\mathrm{NO}_{3}^{-}$(Lachat Instruments, Milwaukee, Wisconsin, USA).

\section{Gas flux measurements}

We applied the static chamber approach (Livingston and Hutchinson 1995) to measure soil-atmosphere and water-atmosphere gas fluxes, and therefore positioned the enclosures to avoid large plants and trees. As a result, our $\mathrm{CO}_{2}$ flux measurements do not encompass photosynthetic uptake and should be interpreted as soil fluxes. At each sampling location, we installed a soil collar $(15 \mathrm{~cm}$ tall $\times 20 \mathrm{~cm}$ diameter PVC pipe) to a depth of $\sim 5 \mathrm{~cm}$ in the soil. Chamber tops were built from opaque 20-cm molded PVC caps with gas-tight rubber gaskets by adding a $0.6 \mathrm{~cm}$ (one-quarter inch) Swagelok brass sampling port with rubber septum, vent tube, internal fan $\left(0.003 \mathrm{~m}^{3} / \mathrm{s}\right.$ [7 cubic feet per minute]; Jameco Electronics, Belmont, California, USA) to each cap (adapted from Livingston and Hutchinson 1995 and McLain et al. 2002). Litter was not removed from inside the soil collar, but herbaceous vegetation (if present) inside the collar was clipped to $10 \mathrm{~cm}$ to place the chamber top on the collar. Clipping or removal of emergent wetland plants has been shown to substantially decrease methane emissions in some natural wetlands (Laanbroek 2010), but not in others (Kelker and Chanton 1997, Altor and Mitsch 2006, Laanbroek 2010). Given that trees were the dominant vegetation in all of our sites except for the agricultural field, we were constrained in our ability to enclose the vegetation in any realistic way. Our measures of soil effluxes allow comparison across sites.

Gas samples were collected once every two months from July 2007 to June 2009 ( $n=11$; November 2008 was not sampled), with all sites and sampling points visited during three consecutive sampling days. We collected $10-\mathrm{mL}$ headspace samples with a glass syringe immediately following cap placement and after each of two intervals of 30-40 min. Gas samples were collected in triplicate and injected into 9-mL pre-evacuated glass vials (Teledyne Tekmar, Mason, Ohio, USA). A total of 5165 gas samples were collected during the two-year study. Air temperature, barometric pressure, and soil temperature at $5 \mathrm{~cm}$ were recorded at the beginning of each sampling interval. Chamber height, water depth, and redox potentials were recorded once for each location on each sampling date. Redox potentials were measured using the installed platinum redox probes, a voltmeter, and a calomel reference electrode (Fisher Scientific, Pittsburgh, Pennsylvania, USA), and values were corrected by adding $241 \mathrm{mV}$ (Vepraskas and Faulkner 2001). The median value of the five redox probes was used in subsequent data analyses. Piezometers (wetter locations) and lysimeters (drier conditions) installed at a depth of $15 \mathrm{~cm}$ were sampled in conjunction with gas flux measurements to determine soil water chemistry. Samples were analyzed for sulfate 
TABle 1. General soil characteristics $(0-15 \mathrm{~cm}$ depth) of the study site in North Carolina, USA.

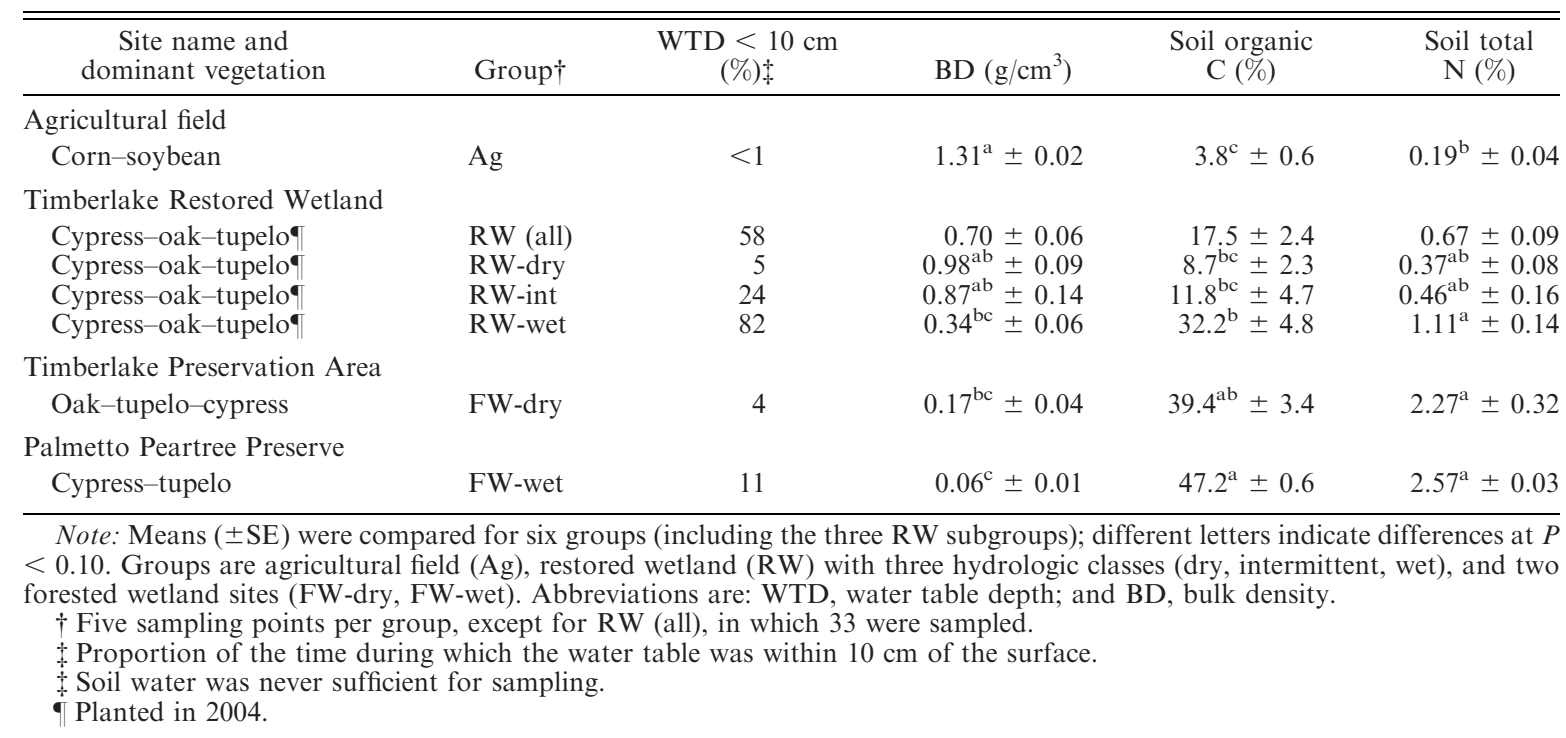

$\left(\mathrm{SO}_{4}\right)$ concentrations by ion chromatography (for an indepth description, see Ardón et al. 2010a).

When surface water was above $10 \mathrm{~cm}$, we used a similar approach, except that a floating PVC collar imbedded in a polystyrene platform was used to capture water-air gas exchange. For floating collar samples, water samples for determination of dissolved gas concentrations were collected in $120-\mathrm{mL}$ pre-evacuated glass bottles during each incubation, and headspace equilibration techniques were used to extract a $10-\mathrm{mL}$ gas sample for analysis (Hudson 2004). Water temperature and volume of the water sample were also measured.

Gas samples were analyzed for $\mathrm{CO}_{2}, \mathrm{~N}_{2} \mathrm{O}$, and $\mathrm{CH}_{4}$ concentrations injected by a Tekmar 7050 Headspace Autosampler to a Shimadzu 17A gas chromatograph with electron capture detector (ECD) and flame ionization detector (FID; Shimadzu Scientific Instruments, Columbia, Maryland, USA), retrofitted with sixport valves and a methanizer to allow the determination of the three gases from the same sample. Ultra-high purity $\mathrm{N}_{2}$ was used as the carrier gas, and a P5 mixture served as the make-up gas for the ECD. A Nafion tube (Perma Pure, Toms River, New Jersey, USA) and counter-current medical breathing air were used to remove water vapor from the sample stream. Samples were analyzed as soon as feasible after collection, and always within two weeks (sample holding time was determined to be at least two weeks during laboratory testing). Peak areas of samples and known standards were determined with GCsolution software version 2.3 (Shimadzu Scientific Instruments 2004) and exported to a Microsoft Access database for data storage. Gas concentrations in vials were calculated from linear regression $\left(r^{2}>0.95\right)$ of concentrations of certified primary standards (Airgas, Morrisville, North Carolina,
USA) against peak areas; concentrations of field samples were obtained by averaging values from duplicate samples analyzed in the same analytical batch, unless the relative percent difference exceeded $20 \%$, in which case the maximum value was used (assuming that a vial had leaked since field sampling).

Under ideal conditions, gases accumulate (or are consumed) linearly over time during static chamber incubations, and the slope of the concentration vs. incubation time is used to estimate the flux. Static chambers are sensitive to disturbance and chamber effects; gas fluxes can be underestimated due to chamber effects if high concentrations in the chamber limit the diffusion of gases from soil to atmosphere (Livingston and Hutchinson 1995). Therefore, we excluded incubations with elevated initial concentrations (attributed to disturbance). From replicate determinations of known standards for each gas, we calculated the minimum detectable concentration difference for each sampling date (MDCD; Yates et al. 2006, Matson et al. 2009). To estimate gas flux, the slope of the concentration vs. time line was used when $r^{2}>0.90$. When the accumulation rate was nonlinear, and the change in concentration during the first interval was greater than MDCD, we used the rate during the first interval; when a longer incubation was needed to exceed MDCD, we used the rate calculated from the initial to the final sample. Incubations in which the concentration increased significantly then decreased significantly, or vice versa, were excluded from the data set as failed incubations (see Appendix: Table A1), while incubations during which there was no detectable concentration change were set to zero. Gas concentrations $\left(\mathrm{g} / \mathrm{cm}^{3}\right)$ were multiplied by chamber height to report flux rates by surface area. 
TABLE 1. Extended.

\begin{tabular}{|c|c|c|c|c|c|}
\hline $\mathrm{C}: \mathrm{N}$ & $\begin{array}{c}\mathrm{NH}_{4}-\mathrm{N} \\
(\mathrm{mg} \mathrm{N} / \mathrm{kg}) \\
\end{array}$ & $\begin{array}{c}\mathrm{NO}_{3}-\mathrm{N} \\
(\mathrm{mg} \mathrm{N} / \mathrm{kg})\end{array}$ & $\mathrm{pH}$ & $\begin{array}{c}\text { Redox } \\
\text { potential }(\mathrm{mV})\end{array}$ & $\begin{array}{c}\text { Soil water } \\
\mathrm{SO}_{4}(\mathrm{mg} / \mathrm{L})\end{array}$ \\
\hline $19.5^{\mathrm{b}} \pm 0.5$ & $0.698^{\mathrm{b}} \pm 0.006$ & $71.1^{\mathrm{c}} \pm 5.07$ & $5.53^{\mathrm{a}}$ & $367^{\mathrm{a}} \pm 30.4$ & NA§ \\
\hline $\begin{array}{r}25.0 \pm 0.7 \\
22.5^{\mathrm{ab}} \pm 1.3 \\
23.5^{\mathrm{ab}} \pm 1.6 \\
28.7^{\mathrm{a}} \pm 1.5\end{array}$ & $\begin{array}{l}14.4 \pm 5.98 \\
1.63^{\mathrm{b}} \pm 0.854 \\
4.47^{\mathrm{b}} \pm 3.74 \\
49.6^{\mathrm{a}} \pm 19.7\end{array}$ & $\begin{array}{r}54.9 \pm 7.14 \\
49.1^{\mathrm{c}} \pm 5.61 \\
42.1^{\mathrm{c}} \pm 4.24 \\
22.3^{\mathrm{c}} \pm 14.6\end{array}$ & $\begin{array}{l}3.84 \\
4.40^{\mathrm{ab}} \\
4.29^{\mathrm{b}} \\
3.75^{\mathrm{b}}\end{array}$ & $\begin{array}{r}-1.61 \pm 14.8 \\
89.3^{\mathrm{b}} \pm 36.6 \\
5.27^{\mathrm{b}} \pm 34.4 \\
-100^{\mathrm{c}} \pm 36.6\end{array}$ & $\begin{array}{r}20.3 \pm 2.1 \\
40.7^{\mathrm{b}} \pm 7.7 \\
46.5^{\mathrm{b}} \pm 8.5 \\
18.7^{\mathrm{c}} \pm 3.6\end{array}$ \\
\hline $17.2^{\mathrm{b}} \pm 0.2$ & $42.3^{\mathrm{a}} \pm 8.85$ & $171^{b} \pm 27.1$ & $4.03^{\mathrm{b}}$ & $12.1^{\mathrm{b}} \pm 19.7$ & $36.6^{\mathrm{b}} \pm 4.5$ \\
\hline $18.4^{\mathrm{b}} \pm 0.2$ & $36.5^{\mathrm{a}} \pm 5.54$ & $367^{\mathrm{a}} \pm 14.4$ & $4.78^{\mathrm{a}}$ & $-180^{c} \pm 19.8$ & $156.8^{\mathrm{a}} \pm 19.7$ \\
\hline
\end{tabular}

To estimate water-atmosphere gas exchange, we determined the concentration of gases dissolved in the water samples (Hudson 2004), the gas transfer velocity using water temperature and the Bunsen coefficient for each gas (Fogg and Sangster 2003), and the change in gas concentrations in the chamber volume during the first time interval of the incubations (Conrad and Seiler 1988, MacIntyre et al. 1995).

\section{Data analysis}

Field and analytical data files were assimilated and manipulated within a relational database in Microsoft Access. Data files were extracted for flux calculations and statistical analyses using the $\mathrm{R}$ programming language ( $\mathrm{R}$ Development Core Team 2009) and its RODBC package (Ripley and Lapsley 2009). In order to compare across sites for which we had differential sampling intensity, $(n=5$ at each reference site vs. $n=33$ in RW), we created three post hoc groupings of sampling points in RW, choosing sites with (1) the fewest missing values for GHG fluxes; and (2) daily mean water table depth (WTD), such that $n=5$ for each group: typically dry, RW-dry (WTD $<-20 \mathrm{~cm}$ ); intermittently wetted, RW-int (WTD between -15 and $-5 \mathrm{~cm}$ ); and typically flooded, RW-wet (WTD $>10 \mathrm{~cm}$ ).

For statistical comparisons, performing parametric tests such as ANOVA to detect group differences was not appropriate because results were not normally distributed. Instead of relying on a theoretical normal probability distribution, we used a resampling approach that essentially exchanges the group labels (Ag, RW-dry, RW-int, RW-wet, FW-dry, FW-wet) attached to observations and generates a distribution of test statistics by Monte Carlo sampling (Good 2000). Specifically, we used permutation one-way tests with adjusted $P$ values for multiple comparisons between groups (oneway_test and Nemenyi-Damico-Wolfe-Dunn test, $\mathrm{R}$ package coin; Hothorn et al. 2008). This method was used to determine whether gas fluxes and soil properties differed between groups. Tests on $\mathrm{pH}$ data were conducted on hydrogen ion concentrations, before transforming results back to $\mathrm{pH}$ notation. We converted $\mathrm{N}_{2} \mathrm{O}$ and $\mathrm{CH}_{4}$ to $\mathrm{CO}_{2}$ equivalents by multiplying by 298 and 25 , respectively, based on the 100-year time horizon estimates in the IPCC's Fourth Assessment Report (Forster et al. 2007). To estimate cumulative annual fluxes, we calculated the areas under each curve (minimum, mean, and maximum) over the two-year period using the trapezoidal rule (trap.rule, R package Hmisc; Harrell 2009).

\section{RESULTS}

\section{Environmental variables as potential drivers of GHG fluxes}

During the two years of this study, data from air temperature loggers did not differ among sites (Fig. 2). Daily mean air temperature during the study was $16.0^{\circ} \mathrm{C}$, with an overall range of $-14^{\circ}$ to $41^{\circ} \mathrm{C}$. Seasonal patterns in water table depth were similar across the restored (RW) and forested (FW) wetland sites, differing only in the amplitude of seasonal variation, while the water table was below our shallow leveloggers for most of the year in the agricultural site (Ag; Fig. 2). In the wetlands, water levels were low in the mid- to lategrowing season, began rising during October through May, and fell again in the early summer. This pattern did not closely track air temperature trends, especially during the warming season when temperatures and water levels both tended to rise. Average daily mean soil temperatures at $15 \mathrm{~cm}$ were higher in the driest sites $\left(17^{\circ} \mathrm{C}\right.$ in $\mathrm{Ag}$ and $15^{\circ} \mathrm{C}$ in $\mathrm{RW}$-dry) and intermittently flooded sites $\left(14.1^{\circ} \mathrm{C}\right.$ in $\mathrm{RW}$-int and $12.7^{\circ} \mathrm{C}$ in $\mathrm{FW}$-dry), compared to the two wettest sites $\left(11.0^{\circ} \mathrm{C}\right.$ in both RWwet and FW-wet; $P<0.001$; data not shown).

Sites within all three wetlands exhibited marked overall differences in water table depth and variation. The daily mean WTD was within $10 \mathrm{~cm}$ of the surface less than $1 \%$ of the time in the actively drained Ag field, $4 \%$ in FW-dry, and $11 \%$ of the time in FW-wet (Fig. 2). The $15 \mathrm{~cm}$ depth of wells in $\mathrm{Ag}$ was too shallow to record many valid measurements of WTD, as active drainage maintained low water tables for agricultural purposes (Fig. 2). The RW was much wetter overall, 

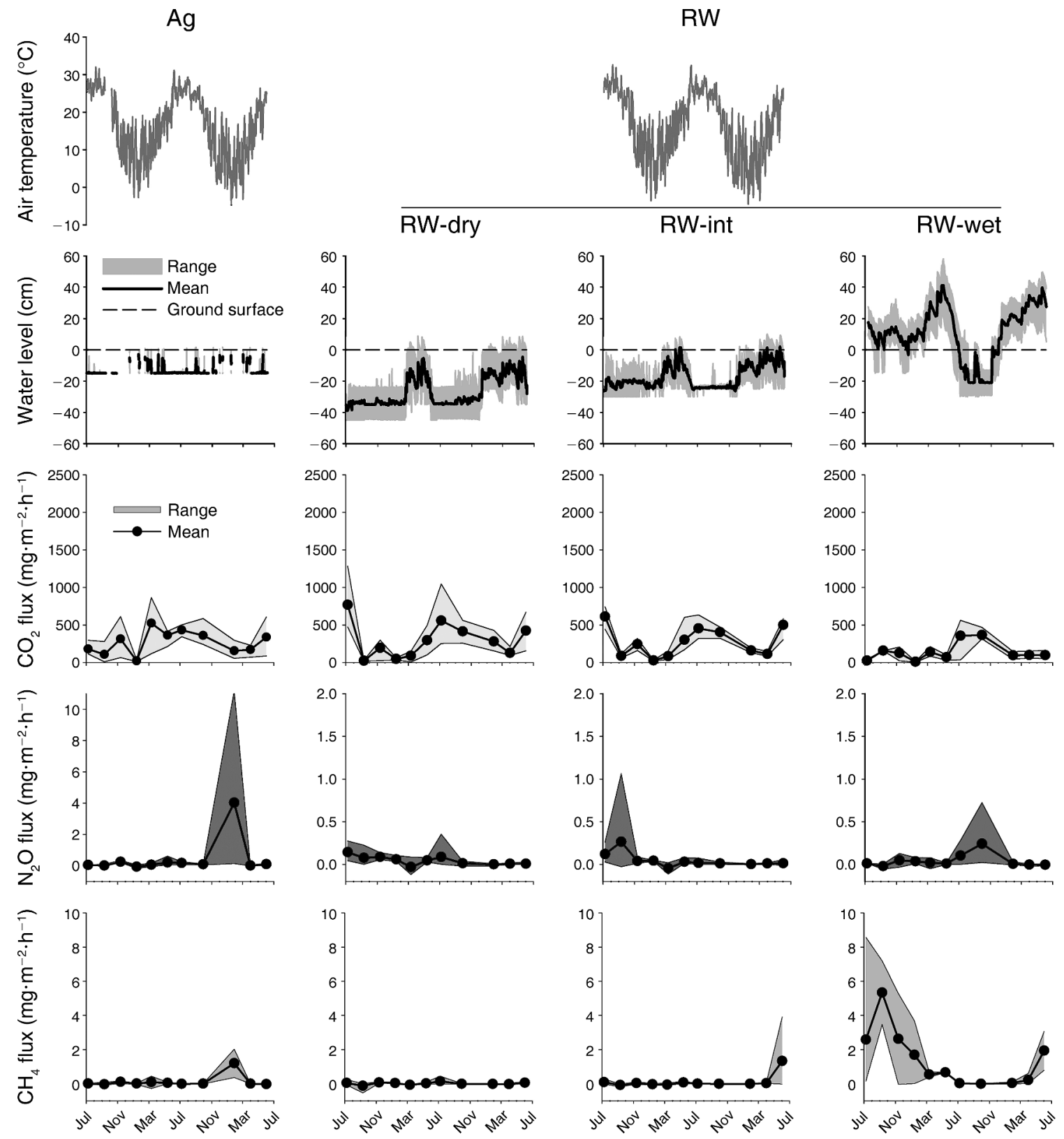

FIG. 2. Temporal and spatial patterns in environmental variables and greenhouse gas (GHG) fluxes (July 2007-June 2009) by site: agricultural field (Ag), restored wetland (RW) with three hydrologic classes (dry, intermittent, wet), and two forested wetland sites (FW-dry, FW-wet). Data are presented for air temperature, water level (daily mean and range), soil $\mathrm{CO}_{2}$ flux, $\mathrm{N}_{2} \mathrm{O}$ fluxes, and $\mathrm{CH}_{4}$ fluxes.

with WTD within $10 \mathrm{~cm}$ of the surface $58 \%$ of the time; surface water was recorded $27 \%$ of the time. Within $\mathrm{RW}$, water table was within $10 \mathrm{~cm}$ of the surface $5 \%$ of the time in the dry subgroup (RW-dry), $24 \%$ of the time in the intermittent subgroup (RW-int), and $82 \%$ of the time in the wet subgroup (RW-wet; Fig. 2).

We examined soil properties by group based on the three reference sites and the three hydrologic subgroups in RW. For most soil characteristics (bulk density, soil organic $\mathrm{C}$, total $\mathrm{N}, \mathrm{KCl}$-extractable $\mathrm{N}$, and redox potential), the clearest differences among sites were seen between the agricultural field and the forested wetlands, with areas within the restored wetland generally in the middle along the dry-to-wet gradient (Table 1). Ag had higher bulk density $(P<0.038)$ and lower soil organic carbon $(P<0.080)$ and total $\mathrm{N}(P<0.010)$ compared to the three wetter sites (two forested wetlands and RWwet). Portions of the restored wetland that were rarely or intermittently flooded (RW-dry and RW-int) had statistically higher BD and lower SOC only compared 

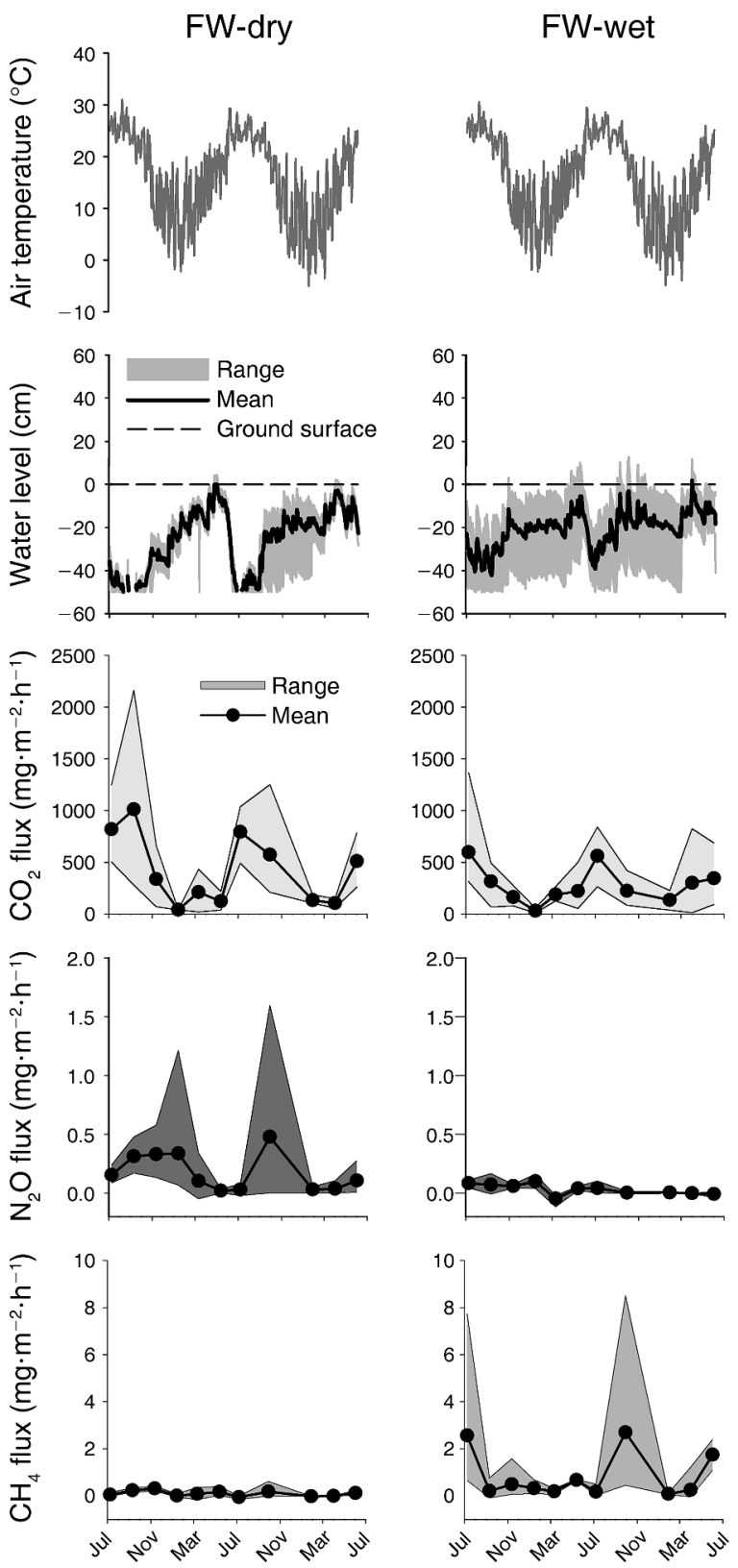

FIG. 2. Continued.

to $\mathrm{FW}$-wet $(P<0.009$ and $P<0.032$, respectively; Table 1). KCl-extractable $\mathrm{NH}_{4}-\mathrm{N}$ was significantly lower in the three driest sites compared to the three wettest sites ( 0.7 to 4.5 vs. 42.3 to $49.6 \mathrm{mg} \mathrm{N} / \mathrm{kg} ; P<$ 0.08 ; Table 1). Redox potential measurements showed three clear groupings: Ag soils were generally oxic (367 $\mathrm{mV})$, the three sites with intermediate hydrology were similar (5.27-89.3 mV at RW-int, FW-dry, and RWdry), and the two wettest sites had reducing environments $(-100$ and -180 at RW-wet and FW-dry, respectively; Table 1).

Soil variables that did not follow the dry-to-wet gradient were soil $\mathrm{C}: \mathrm{N}$, soil $\mathrm{pH}$, and $\mathrm{KCl}$-extractable
$\mathrm{NO}_{3}^{-}$. Soil $\mathrm{C}: \mathrm{N}$ ratios were highest in the typically flooded portions of the restored wetland (28.7 in RWwet), compared to the three reference sites (17.2 to 19.5; $P<0.07)$. The $\mathrm{Ag}$ and $\mathrm{FW}$-wet sites had higher $\mathrm{pH}$ than RW-wet, FW-dry, and RW-int sites (5.53 and 4.78 vs. 3.75 to $4.29 ; P<0.096$ ). The two forested wetlands were significantly higher than the other sites in $\mathrm{KCl}$ extractable $\mathrm{NO}_{3}-\mathrm{N}(P<0.001$; Table 1). Over the entire sampling period, mean $\mathrm{SO}_{4}$ concentrations in soil solution were highest in $\mathrm{FW}$-wet $(156.8 \mathrm{mg} / \mathrm{L} ; P<$ 0.001 ), while in $\mathrm{FW}$-dry and RW values ranged from 18.7 to $46.5 \mathrm{mg} / \mathrm{L}$ (Table 1). Efforts to produce simple multiple linear regressions to explain GHG flux based on environmental variables across all observations were unsuccessful.

\section{Greenhouse gas fluxes: temporal and spatial patterns}

Soil $\mathrm{CO}_{2}$ fluxes were strongly seasonal throughout the RW sites and the adjacent forested wetland (FW-dry), with high measured rates during the warmest months (maximum at FW-dry in September 2007; $2160 \mathrm{mg}$ $\left.\mathrm{CO}_{2} \cdot \mathrm{m}^{-2} \cdot \mathrm{h}^{-1}\right)$ and very low rates during the coldest months $\left(<20 \mathrm{mg} \mathrm{CO}{ }_{2} \cdot \mathrm{m}^{-2} \cdot \mathrm{h}^{-1}\right)$. In contrast, soil $\mathrm{CO}_{2}$ fluxes measured in the $\mathrm{Ag}$ site were generally lower and did not track changes in temperature (Fig. 2). Mean soil $\mathrm{CO}_{2}$ fluxes were not statistically different between $\mathrm{Ag}$, RW-dry, RW-int, FW-dry, and FW-wet, ranging from $290 \mathrm{mg} \mathrm{CO} \cdot \mathrm{m}^{-2} \cdot \mathrm{h}^{-1}$ in $\mathrm{Ag}$ to $472 \mathrm{mg} \mathrm{CO} \cdot \mathrm{m}^{-2} \cdot \mathrm{h}^{-1}$ in FW-dry (Fig. 3; Appendix: Table A1), but were significantly lower in RW-wet $\left(150 \mathrm{mg} \mathrm{CO} \cdot \mathrm{m}^{-2} \cdot \mathrm{h}^{-1} ; P\right.$ $<0.046)$ compared to all other sites.

Soil $\mathrm{N}_{2} \mathrm{O}$ fluxes were also seasonal throughout the restored wetland and adjacent forested wetland (RW and FW-dry); however, the magnitude of these seasonal changes in the restored wetland and forested wetlands was dwarfed by very high fluxes measured in the $\mathrm{Ag}$ site in January $2009\left(11.2 \mathrm{mg} \mathrm{N} \mathrm{N}_{2} \mathrm{O} \cdot \mathrm{m}^{-2} \cdot \mathrm{h}^{-1}\right.$; Fig. 2). $\mathrm{N}_{2} \mathrm{O}$ fluxes in $\mathrm{FW}$-wet were uniformly low throughout the study period. Mean $\mathrm{N}_{2} \mathrm{O}$ fluxes were very low across the three RW groups and FW-wet $(0.030-0.065 \mathrm{mg}$ $\mathrm{N}_{2} \mathrm{O} \cdot \mathrm{m}^{-2} \cdot \mathrm{h}^{-1} ; P<0.027$ ), while the highest average $\mathrm{N}_{2} \mathrm{O}$ flux, as well as the greatest temporal variation in $\mathrm{N}_{2} \mathrm{O}$ fluxes, were measured in the $\mathrm{Ag}$ site $(0.46 \pm 0.27$ $\mathrm{mg} \mathrm{N} \mathrm{N}_{2} \mathrm{O} \cdot \mathrm{m}^{-2} \cdot \mathrm{h}^{-1}$; Fig. 3B; Appendix: Table A1).

Methane fluxes were occasionally high, and highly variable over time, in both RW and FW-wet, with high fluxes measured during warm months $(8.50$ and $8.58 \mathrm{mg}$ $\mathrm{CH}_{4} \cdot \mathrm{m}^{-2} \cdot \mathrm{h}^{-1}$; Fig. 2).This pattern was not consistent across all sites, nor in all warm months; for example, the largest $\mathrm{CH}_{4}$ fluxes in the $\mathrm{Ag}$ site were measured in January 2009, while $\mathrm{CH}_{4}$ fluxes in FW-dry were consistently low (Fig. 2). Mean $\mathrm{CH}_{4}$ fluxes differed across the sites, with significantly higher fluxes at the two wettest sites (FW-wet and $\mathrm{RW}$-wet) compared to the other sites $\left(0.94\right.$ and $1.2 \mathrm{mg} \mathrm{CH} \mathrm{CH}_{4} \cdot \mathrm{m}^{-2} \cdot \mathrm{h}^{-1}$, respectively; $P<0.012$; Fig. 3C; Appendix: Table A1).

Soil $\mathrm{CO}_{2}$ fluxes tended to show similar qualitative changes between dates across all sites (Fig. 2). In 

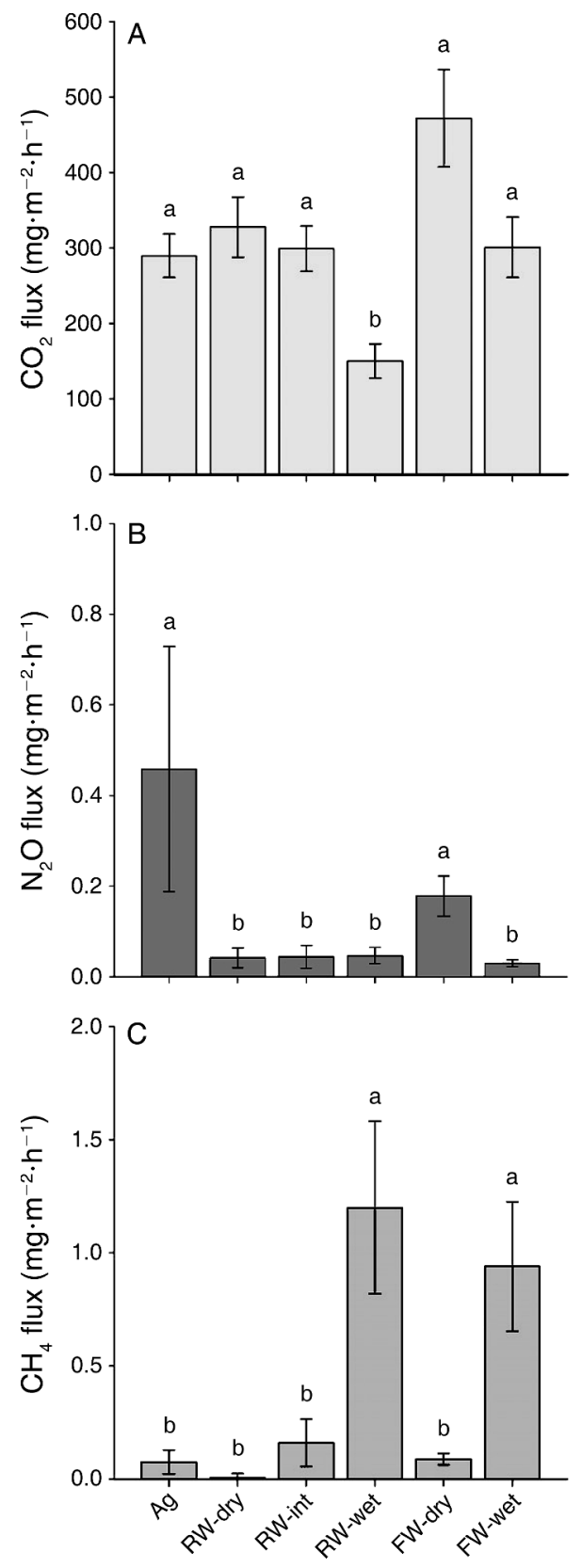

FIG. 3. Mean $( \pm \mathrm{SE})$ greenhouse gas $(\mathrm{GHG})$ fluxes over two years by site: agricultural field (Ag), restored wetland (RW) with three hydrologic classes (dry, intermittent, wet), and two forested wetland sites (FW-dry, FW-wet). (A) soil $\mathrm{CO}_{2}$ flux, (B) $\mathrm{N}_{2} \mathrm{O}$ fluxes, and (C) $\mathrm{CH}_{4}$ fluxes. Different letters indicate statistical differences between sites $(P<0.1)$.

contrast, the highest and lowest fluxes of $\mathrm{N}_{2} \mathrm{O}$ and $\mathrm{CH}_{4}$ did not occur on the same sampling date across sites (Fig. 2). Within the Ag site, temporal variability was very high and driven by observations in January 2009, when the range of measured $\mathrm{N}_{2} \mathrm{O}$ fluxes was over 10 times larger than the range of values measured there during the rest of the study (Fig. 2).
Greenhouse gas fluxes: cumulative annual fluxes

We integrated the curves describing variation in the minimum, mean, and maximum GHG fluxes measured on each sampling date to estimate annual fluxes for each gas at each of the six sites (Fig. 2; Appendix: Table A2). We used the ratio of the range to the mean (Levins and Lopez 1999) of the annual fluxes to describe the variability of our estimates. We found that the overall range to mean ratio for $\mathrm{CO}_{2}$ was $150 \%$, compared to $450 \%$ for $\mathrm{N}_{2} \mathrm{O}$ and $557 \%$ for $\mathrm{CH}_{4}$, and that the variability for $\mathrm{CO}_{2}$ and $\mathrm{N}_{2} \mathrm{O}$ was more consistent across sites than it was for $\mathrm{CH}_{4}$ (Appendix: Table A2). The variability of cumulative $\mathrm{CO}_{2}$ flux ranged from $62 \%$ to $110 \%$ within the restored wetland, while in the reference sites the variability of cumulative $\mathrm{CO}_{2}$ fluxes ranged from $110 \%$ to $155 \%$. The pattern of variability in estimated cumulative fluxes was reversed for $\mathrm{N}_{2} \mathrm{O}$ and $\mathrm{CH}_{4}$ : Variability was greater within the restored wetland than in the reference sites $\left(\mathrm{N}_{2} \mathrm{O}, 302-378 \%\right.$ in $\mathrm{RW}$ vs. $224-264 \%$ in reference sites; $\mathrm{CH}_{4}: 145-2740 \%$ in $\mathrm{RW}$ vs. 192-248\% in reference sites; Appendix: Table A2).

The flooded portions of the restored wetland had low $\mathrm{CO}_{2}$ fluxes $\left(1.3 \times 10^{4} \mathrm{~kg} \mathrm{CO} \cdot \mathrm{ha}^{-1} \cdot \mathrm{yr}^{-1}\right)$, while the adjacent forested wetland (FW-dry) had three times higher cumulative soil $\mathrm{CO}_{2}$ flux $\left(4.3 \times 10^{4} \mathrm{~kg}\right.$ $\left.\mathrm{CO}_{2} \cdot \mathrm{ha}^{-1} \cdot \mathrm{yr}^{-1}\right)$. High cumulative $\mathrm{N}_{2} \mathrm{O}$ fluxes were measured in the agricultural field $\left(51 \mathrm{~kg} \mathrm{~N}_{2} \mathrm{O} \cdot \mathrm{ha}^{-1} \cdot \mathrm{yr}^{-1}\right)$, with the cumulative mean estimate strongly driven by fluxes measured on a single date (Appendix: Table A2). The adjacent forested wetland (FW-dry) also had high cumulative $\mathrm{N}_{2} \mathrm{O}$ fluxes, due to more consistent elevated $\mathrm{N}_{2} \mathrm{O}$ fluxes $\left(16.2 \mathrm{~kg} \mathrm{~N} \mathrm{~N}_{2} \mathrm{O} \cdot \mathrm{ha}^{-1} \cdot \mathrm{yr}^{-1}\right)$. In contrast, all three hydrologic subgroups within the restored wetland had low mean annual $\mathrm{N}_{2} \mathrm{O}$ fluxes $(3.37-4.52 \mathrm{~kg}$ $\mathrm{N}_{2} \mathrm{O} \cdot \mathrm{ha}^{-1} \cdot \mathrm{yr}^{-1}$; Appendix: Table A2). Relatively high $\mathrm{CH}_{4}$ mean annual fluxes were calculated for the two wettest sites (the flooded portions of the restored wetland [RW-wet] and the more frequently inundated forested wetland [FW-wet]) as 107 and $71.6 \mathrm{~kg}$ $\mathrm{CH}_{4} \cdot \mathrm{ha}^{-1} \cdot \mathrm{yr}^{-1}$ (respectively), while values from the other sites were much lower $\left(0.53-14.3 \mathrm{~kg} \mathrm{CH} \cdot \mathrm{ha}^{-1} \cdot \mathrm{yr}^{-1}\right.$; Appendix: Table A2).

We converted mean annual rates of $\mathrm{N}_{2} \mathrm{O}$ and $\mathrm{CH}_{4}$ emissions into $\mathrm{CO}_{2}$ equivalents to compare their cumulative contributions to global radiative balance (Fig. 4A; Bridgham et al. 2006). For all groups, the main component of GHG fluxes was soil $\mathrm{CO}_{2}$ flux. The FWdry site had relatively high radiative balance overall (527 $\mathrm{mg} \mathrm{CO}$ equivalents $\cdot \mathrm{m}^{-2} \cdot \mathrm{h}^{-1}$ ), but was only statistically distinguishable from $\mathrm{RW}$-wet $(P=0.037$; Fig. 4A). Because we estimated net fluxes of $\mathrm{N}_{2} \mathrm{O}$ and $\mathrm{CH}_{4}$, but not of $\mathrm{CO}_{2}$ (photosynthesis was not measured), we also show the comparison of $\mathrm{CO}_{2}$ equivalents for $\mathrm{N}_{2} \mathrm{O}$ and $\mathrm{CH}_{4}$ only (Fig. $4 \mathrm{~B}$ ). In this scenario, $\mathrm{N}_{2} \mathrm{O}$ is the most important contributor to the radiative balance, except in FW-wet and RW-wet, in which $\mathrm{CH}_{4}$ was the largest source. Based on $\mathrm{N}_{2} \mathrm{O}$ and $\mathrm{CH}_{4}$, the two drier hydrologic classes in RW are statistically lower in $\mathrm{CO}_{2}$ 
equivalents compared to Ag, FW-dry, and FW-wet $(P<$ 0.01; Fig. 4B).

\section{DisCUSSION}

\section{GHG fluxes as a function of land use and environmental variables}

Our primary motivation for this research effort was to determine whether reinstating wetland hydrology in former agricultural fields would result in enhanced production of $\mathrm{N}_{2} \mathrm{O}$ and $\mathrm{CH}_{4}$ (as suggested by Verhoeven et al. 2006). We found that $\mathrm{N}_{2} \mathrm{O}$ fluxes were lower across this restored forested wetland than in nearby managed agricultural fields and one of two unmanaged forested wetlands. Methane emissions were enhanced in permanently flooded areas of the restored wetland; however, in the flooded soils (RW-wet and $\mathrm{FW}$-wet) where $\mathrm{CH}_{4}$ fluxes were highest, soil respiration was low enough that differences in total GHG emissions $\left(\mathrm{CO}_{2}, \mathrm{~N}_{2} \mathrm{O}\right.$, and $\mathrm{CH}_{4}$ ) were not significantly different among the contrasting land uses (agriculture, restored wetland, forested wetland; Fig. 4A).

Since we did not estimate rates of photosynthesis, our $\mathrm{CO}_{2}$ fluxes cannot be considered net ecosystem fluxes. Soil $\mathrm{CO}_{2}$ fluxes have been shown to be negatively correlated with aboveground biomass (Tyree et al. 2006), so the restored wetland's long-term potential as a $\mathrm{CO}_{2}$ sink is strong, given that our $\mathrm{CO}_{2}$ flux estimates included root respiration. In the southeast United States, young oak-gum-cypress stands are estimated to accumulate live biomass at a mean rate of $1.78 \times 10^{3}$ $\mathrm{kg} \mathrm{C} \cdot \mathrm{ha}^{-1} \cdot \mathrm{yr}^{-1}$ in the first 50 years of establishment (Smith et al. 2006). Since this restored wetland is a young, aggrading forest, compared to the conventionally managed $\mathrm{Ag}$ site and the two mature forested wetlands (FW-dry and FW-wet), the restored wetland undoubtedly represents a stronger $\mathrm{CO}_{2}$ sink in soils and plant biomass (Odum 1969, Pregitzer and Euskirchen 2004, Peng et al. 2008). Furthermore, if we only consider $\mathrm{N}_{2} \mathrm{O}$ and $\mathrm{CH}_{4}$ fluxes, the drier areas of the restored wetland produced significantly less trace gas $\mathrm{CO}_{2}$ equivalents than either the agricultural field or the forested wetlands (Fig. 4B). Collectively, this evidence would support the idea that the restored wetland did not have higher overall GHG fluxes compared to the reference sites.

We had expected that soil respiration in both reference forested wetlands would be lower than in the $\mathrm{Ag}$ site, as is typically the case for reducing environments (Schlesinger 1997, Peng et al. 2008), but we found no differences. A drought during the first year of the study period likely suppressed soil respiration in the drier $\mathrm{Ag}$ soils and increased soil respiration in the reference forested wetlands, but patterns were not markedly different in the second year, when precipitation patterns were closer to normal (Fig. 2).

We had expected to find relatively higher $\mathrm{N}_{2} \mathrm{O}$ emissions in intermittently flooded sites, resulting from enhanced decomposition and $\mathrm{N}$ mineralization, which in
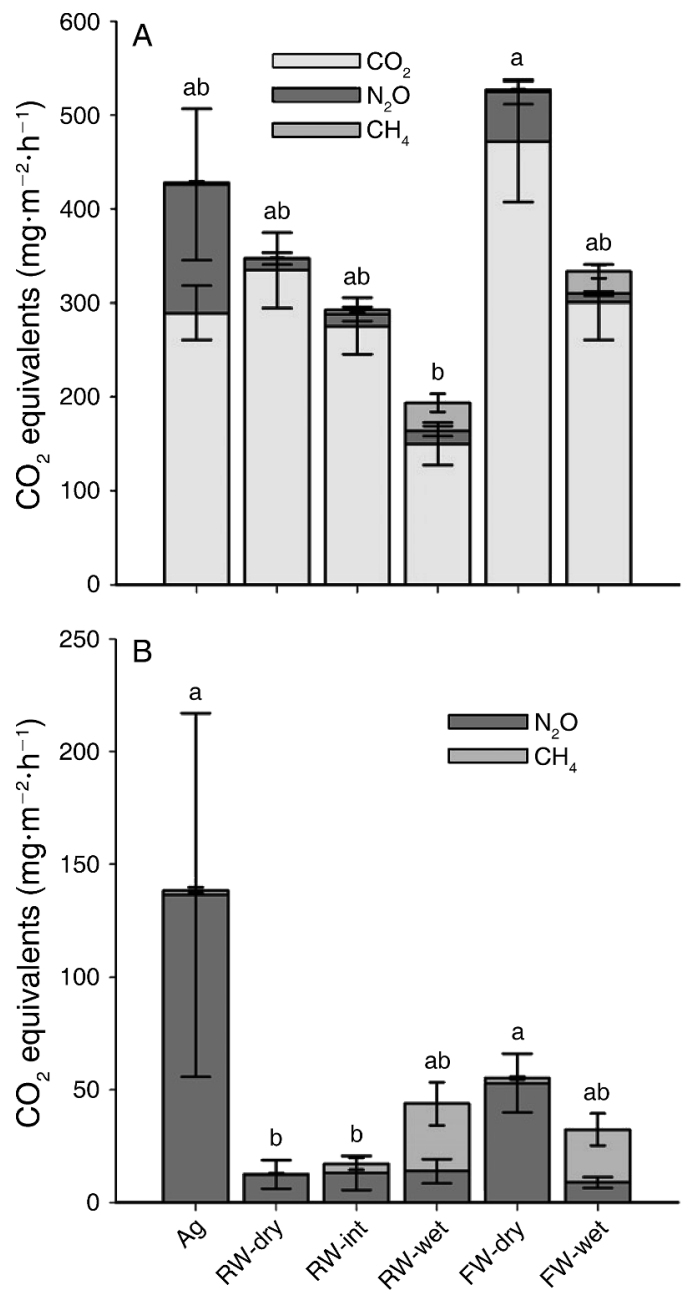

FIG. 4. $\mathrm{CO}_{2}$ equivalents (two-year means) by site: agricultural field $(\mathrm{Ag})$, restored wetland (RW) with three hydrologic classes (dry, intermittent, wet), and two forested wetland sites (FW-dry, FW-wet). (A) Soil respiration $\left(\mathrm{CO}_{2}\right)+298 \times \mathrm{N}_{2} \mathrm{O}+$ $25 \times \mathrm{CH}_{4}$; (B) $\mathrm{N}_{2} \mathrm{O}$ and $\mathrm{CH}_{4}$ only. Different letters indicate statistical differences between sites $(P<0.1)$.

turn would stimulate nitrification and denitrification while suppressing methanogenesis (Reddy and Patrick 1984, Hernandez and Mitsch 2006). We observed this pattern in the drier of the two forested wetlands (FWdry), but not within the restored wetland, where fluxes of $\mathrm{N}_{2} \mathrm{O}$ were low regardless of flooding dynamics. Indeed, the highest $\mathrm{N}_{2} \mathrm{O}$ fluxes were measured in the $\mathrm{Ag}$ site, which had the driest soil conditions, suggesting that hydrological regime was not the only driver (Fig. 2).

Correlations between denitrification and a number of environmental factors are well described, including soil redox potential (optimal at $200 \mathrm{mV}$ ) and soil C:N ratio (low C:N can promote denitrification; Hume et al. 2002, 2007). Based on mean redox potentials of the bulk soil in the intermittently flooded forested wetland (FW-dry; $12 \mathrm{mV}$ ) and in the rarely and intermittently flooded portions of the restored wetland (RW-dry and RW-int; 
89 and $5.3 \mathrm{mV}$, respectively), we would expect that denitrification would be a dominant process in those sites, representing an important source of $\mathrm{N}_{2} \mathrm{O}$ (Megonigal et al. 2004). Of those three sites, soils in FW-dry had much higher $\mathrm{N}$ availability compared to RW-dry and $\mathrm{RW}$-int (based on low soil $\mathrm{C}: \mathrm{N}$ and $\mathrm{KCl}$-extractable $\mathrm{N}$ concentrations; Table 1), which is consistent with the high $\mathrm{N}_{2} \mathrm{O}$ fluxes measured in that site. Nitrification, an aerobic chemolithotrophic microbial process that converts $\mathrm{NH}_{4}{ }^{+}$to $\mathrm{NO}_{3}{ }^{-}$, is another $\mathrm{N}_{2} \mathrm{O}$-generating process that may be significant in sites with intermittent hydrology. Although nitrification is generally thought to be less important than denitrification in contributing to $\mathrm{N}_{2} \mathrm{O}$ fluxes from wetlands (Davidson et al. 2000), it can be a substantial pathway for $\mathrm{N}_{2} \mathrm{O}$ flux in acidorganic wetland soils (De Boer and Kowalchuk 2001, Morse 2010).

In the agricultural site, human manipulations (efficient drainage and fertilization), rather than intermittent flooding, were the likely cause of high $\mathrm{N}_{2} \mathrm{O}$ fluxes we measured there. Soils in the Ag site were very oxic (Table 1), resulting from a system of vee-ditches, canals, and pumps for drainage that maintained the water table $>1 \mathrm{~m}$ below the soil surface. In the absence of intermittent flooding, and with low soil organic matter, the stimulation of nitrification and denitrification of mineralized $\mathrm{N}$ from soil organic matter that would be expected from intermittent flooding was less likely in this site.

The very high measured $\mathrm{N}_{2} \mathrm{O}$ fluxes in January 2009 suggested that $\mathrm{N}$ fertilization might be involved. Based on personal communication with the farm manager, we learned that the Ag site was generally fertilized in early winter (December/January) and early spring (March), in advance of that year's corn crop. Water samples collected from the farm's drainage canal during January 2009 had mean $\mathrm{NO}_{3}-\mathrm{N}$ concentrations two orders of magnitude higher than what was measured in MayNovember 2008 (1.68 vs. 0.052 mg NO$-\mathrm{N} / \mathrm{L}$; Ardón et al. 2010b). Other periods of high $\mathrm{NO}_{3}{ }^{-}$concentrations in Ag drainage water did occur during our study, but were not associated with high $\mathrm{N}_{2} \mathrm{O}$ fluxes, perhaps due to lags in gas sampling following fertilization, differences in soil moisture and temperature that might have suppressed $\mathrm{N}_{2} \mathrm{O}$ fluxes, or different fertilization practices for other crops. Because temperatures were around $8^{\circ} \mathrm{C}$ during the week prior to and the day of sampling in January 2009, it is unlikely that the high $\mathrm{N}_{2} \mathrm{O}$ flux was the result of freeze-thawing, a pathway that has been shown to be important for northern forests in winter and spring (Papen and Butterbach-Bahl 1999, Groffman et al. 2009, Eberling et al. 2010). This $\mathrm{N}_{2} \mathrm{O}$ pulse was not seen in our other sites on this date, supporting this conclusion.

Our hypotheses for $\mathrm{CH}_{4}$ were that continuously flooded sites would have the highest fluxes; according to our soil redox measurements, methanogenesis (optimal at $-400 \mathrm{mV}$; Megonigal et al. 2004) would be likely to dominate in the wetter forested wetland (FW-wet) and the flooded portions of the restored wetland (RWwet; mean of $-180 \mathrm{mV}$ and $-100 \mathrm{mV}$, respectively). We did find that $\mathrm{CH}_{4}$ fluxes were highest in these two sites. In the $\mathrm{Ag}$ site, the highest $\mathrm{CH}_{4}$ flux was also measured during January 2009, which could be the result of wetter soils or reduced $\mathrm{CH}_{4}$ consumption with higher $\mathrm{N}$ availability: $\mathrm{NH}_{4}^{+}$can suppress $\mathrm{CH}_{4}$ consumption by $\mathrm{CH}_{4}$ oxidizers, while $\mathrm{NO}_{3}{ }^{-}$can raise the redox potential of soils (Le Mer and Roger 2001, Liu and Greaver 2009).

While sulfate in soil or surface water is another factor that can suppress methanogenesis, because sulfate reduction is more thermodynamically favorable than methanogenesis (Megonigal et al. 2004), the presence of sulfate is unlikely to have limited $\mathrm{CH}_{4}$ production in the drier sites. In the more flooded areas, sulfate concentrations were clearly not high enough to suppress $\mathrm{CH}_{4}$ production altogether, as is commonly seen in brackish waters (e.g., Neubauer et al. 2005). For $97 \%$ of our $\mathrm{CH}_{4}$ flux measurements, water tables were too low to be sampled or sulfate concentrations were below $100 \mathrm{ppm}$. When no soil water could be sampled $\left(79 \%\right.$ of $\mathrm{CH}_{4}$ observations), $\mathrm{CH}_{4}$ fluxes averaged $215 \pm 3.0$ $\mu \mathrm{g} \cdot \mathrm{m}^{-2} \cdot \mathrm{h}^{-1}$.(means $\pm \mathrm{SE}$ ) When $\mathrm{SO}_{4}$ concentrations were below 100 ppm, mean $\mathrm{CH}_{4}$ flux was $850 \pm 29$ $\mu \mathrm{g} \cdot \mathrm{m}^{-2} \cdot \mathrm{h}^{-1}$, while when $\mathrm{SO}_{4}$ concentrations were above 100 ppm (3\% of the $\mathrm{CH}_{4}$ data set), mean $\mathrm{CH}_{4}$ flux was somewhat lower $\left(515 \pm 62 \mu \mathrm{g} \cdot \mathrm{m}^{-2} \cdot \mathrm{h}^{-1}\right)$. This suggests that, while $\mathrm{CH}_{4}$ flux in wetter sites may be periodically depressed by the availability of sulfate for anaerobes during saltwater intrusion or drought-induced concentration of $\mathrm{SO}_{4}$ (M. Ardón, J. L. Morse, and E. S. Bernhardt, unpublished manuscript), this factor did not dominate our $\mathrm{CH}_{4}$ flux estimates (Table 1).

\section{GHG fluxes in context}

Our study is one of the first to estimate soil fluxes of $\mathrm{CO}_{2}, \mathrm{CH}_{4}$, and $\mathrm{N}_{2} \mathrm{O}$ in the southeast USA, and additionally provides a perspective on wetland restoration. While this restored wetland (440 ha) is one of the largest wetland restoration projects in the eastern USA, it represents only $0.4 \%$ of the total land area of organic soils converted to drained agriculture in North Carolina alone (92 000 ha; C. J. Richardson, personal communication). The opportunity for large-scale wetland restoration in similar coastal plain agricultural lands on former wetlands in North Carolina and other states in the southeast USA is therefore extensive. To put our results in context, we compiled a selection of published studies of GHG fluxes, ranging from northern peatlands and constructed wetlands to tropical forests and agricultural fields; we found few studies that report flux estimates for all three biogenic greenhouse gases (Table 2). We found no clear pattern of GHG flux by latitude, ecosystem, or land use.

Given this context, our $\mathrm{CH}_{4}$ flux rates (mean of $0.53-$ $107 \mathrm{~kg} \cdot \mathrm{ha}^{-1} \cdot \mathrm{yr}^{-1}$; Appendix: Table A2) are especially low for wetlands, compared to the overall mean of 1030 
$\mathrm{kg} \cdot \mathrm{ha}^{-1} \cdot \mathrm{yr}^{-1}$. The highest annual estimate of $\mathrm{CH}_{4}$ flux in our study was in $\mathrm{RW}$-wet, with $259 \mathrm{~kg} \cdot \mathrm{ha}^{-1} \cdot \mathrm{yr}^{-1}$, still far below the mean $\mathrm{CH}_{4}$ flux. While we may have underestimated $\mathrm{CH}_{4}$ fluxes in permanently flooded areas by not specifically measuring ebullition fluxes (MacIntyre et al. 1995), even doubling our estimates would still result in relatively low fluxes. Factors that can suppress $\mathrm{CH}_{4}$ flux to the atmosphere include (1) lack of reducing conditions in soils (lower $\mathrm{CH}_{4}$ production); (2) $\mathrm{CH}_{4}$ consumption in oxic surface soils; and (3) low substrate availability for methanogens (Bridgham and Richardson 1992, Megonigal et al. 2004). The first two factors are most likely to apply to the restored wetland, in which areas with saturated soils might be less reducing (due to more mineral soils with larger pools of reducible iron [Ardón et al. 2010a] or due to high sulfate concentrations [another competing electron acceptor; Megonigal et al. 2004, Neubauer et al. 2005]) and areas with unsaturated surface soils could oxidize $\mathrm{CH}_{4}$ (Le Mer and Roger 2001).

Compiled values for $\mathrm{N}_{2} \mathrm{O}$ fluxes from natural wetlands and other undisturbed ecosystems were relatively low $\left(0-16 \mathrm{~kg} \cdot \mathrm{ha}^{-1} \cdot \mathrm{yr}^{-1}\right.$, except for a Louisiana swamp with $85.6 \mathrm{~kg} \cdot \mathrm{ha}^{-1} \cdot \mathrm{yr}^{-1}$ ) compared to the restored and forested wetlands in our study (5.90 and 8.35 $\mathrm{kg} \cdot \mathrm{ha}^{-1} \cdot \mathrm{yr}^{-1}$, respectively; Table 2). Elevated values were reported in nutrient-rich systems such as constructed wetlands, rice paddies, and especially in agricultural watersheds (up to $946 \mathrm{~kg} \cdot \mathrm{ha}^{-1} \cdot \mathrm{yr}^{-1}$; Table 2). Hydrologic status and $\mathrm{N}$ availability in our study sites together could explain high $\mathrm{N}_{2} \mathrm{O}$ fluxes and low $\mathrm{CH}_{4}$ fluxes in our study relative to natural wetlands, through intermittent flooding that could increase aeration and greater $\mathrm{N}$ mineralization in soils, which would promote $\mathrm{N}_{2} \mathrm{O}$ production from nitrification and denitrification, while lowering net $\mathrm{CH}_{4}$ emissions (Reddy and Patrick 1984, Davidson et al. 2000).

We can also view our $\mathrm{N}_{2} \mathrm{O}$ flux estimates in the context of other $\mathrm{N}$ fluxes we have measured in TLRP. We measured $\mathrm{N}$ inputs from wet deposition during the study period of $6.45 \mathrm{~kg} \mathrm{~N} \cdot \mathrm{ha}^{-1} \cdot \mathrm{yr}^{-1}$; Ardón et al. 2010b); with a mean estimated $\mathrm{N}_{2} \mathrm{O}-\mathrm{N}$ flux across the RW of $2.43 \mathrm{~kg} \mathrm{~N} \cdot \mathrm{ha}^{-1} \cdot \mathrm{yr}^{-1}$, this yields an emission factor of 0.38 in RW. However, if we assume a typical $\mathrm{N}_{2} \mathrm{O}$ mole fraction $\left(\mathrm{N}_{2} \mathrm{O}-\mathrm{N} /\left[\mathrm{N}_{2} \mathrm{O}-\mathrm{N}+\mathrm{N}_{2}-\mathrm{N}\right]\right)$ reported for denitrification in freshwater wetlands and agricultural fields (0.08-0.37; Schlesinger 2009), our estimated N-gas fluxes $\left(6.57-30.4 \mathrm{~kg} \mathrm{~N} \cdot \mathrm{ha}^{-1} \cdot \mathrm{yr}^{-1}\right)$ would be up to 4.7 times higher than atmospheric $\mathrm{N}$ inputs. Assuming our estimates of $\mathrm{N}$-gas flux and atmospheric $\mathrm{N}$ deposition are reasonably accurate, this would imply that (1) there is excess $\mathrm{N}$ available in RW soils (despite lower inorganic $\mathrm{N}$ pools in the restored wetland compared to the other sites), either from legacy $\mathrm{N}$ fertilizers or $\mathrm{N}$ mineralization of soil organic matter; (2) $\mathrm{N}$ fixation is contributing substantially to the N budget of TLRP; or (3) surface water $\mathrm{N}$ inputs are fueling denitrification. Results from water monitoring show that $\mathrm{NO}_{3}-\mathrm{N}$ inputs to the site in surface water (mean of $126.5 \mathrm{~kg} \mathrm{~N} / \mathrm{yr}$ ) exceed $\mathrm{NO}_{3}-\mathrm{N}$ outputs in surface water (mean of $29.9 \mathrm{~kg}$ $\mathrm{N} / \mathrm{yr}$; Ardón et al. 2010b). While denitrification is likely to contribute to this observed $\mathrm{NO}_{3}-\mathrm{N}$ retention for the site, it would account for only $0.22 \mathrm{~kg} \mathrm{~N} \cdot \mathrm{ha}^{-1} \cdot \mathrm{yr}^{-1}$ of our estimated $\mathrm{N}$-gas emissions, which suggests that contributions from $\mathrm{N}$ fixation or soil $\mathrm{N}$ pools must be substantial.

\section{Implications for restoration}

The large extent (440 ha) and hydrologic variability of TLRP are not typical of conventional restored wetlands, which tend to be much smaller in area (Wagner et al. 2008). The extent of TLRP, along with its hydrologic regime (driven by precipitation and evapotranspiration) and low relief, allowed us to identify patterns of GHG fluxes within the RW that were associated with hydrological variables. Such relationships could help us understand the consequences of restoration for the many similar low-lying forested wetlands and peatlands in the Mid-Atlantic region that were converted to drained agriculture (Carter 1975, Dahl 1990), including at least 92000 ha in coastal North Carolina, and lands surrounding the Chesapeake Bay.

Forested wetlands and peatlands commonly feature acidic soils, and this acidity in TLRP persisted despite 20-30 years of agriculture that included liming, among other management practices ( $\mathrm{R}$. Needham, personal communication). Although we expected to find large pools of legacy $\mathrm{N}$ two years after the last crop harvest, based on fertilization history, we found lower soil $\mathrm{N}$ content in the restored wetland compared to forested wetland reference sites. If soil $\mathrm{N}$ pools and $\mathrm{N}_{2} \mathrm{O}$ fluxes in the restored wetland were enhanced by fertilizer-derived $\mathrm{N}$, it is possible that these pools were depleted during the major soil movement to recontour the site and fill drainage ditches, or within the initial two years following cessation of farming.

Contemporary elevated $\mathrm{N}$ inputs to TLRP are therefore external to the system. Based on other work at we conducted at TLRP (Ardón et al. 2010b), inputs of $\mathrm{N}$ to the restored wetland from surface water, rain, and drainage from the $\mathrm{Ag}$ site are equal parts $\mathrm{NH}_{4}-\mathrm{N}, \mathrm{NO}_{3}-$ $\mathrm{N}$, and dissolved organic $\mathrm{N}$. The restored wetland retained $70 \%$ of total $\mathrm{N}$ inputs (retaining $98 \%$ of $\mathrm{NO}_{3}-\mathrm{N}$ and $25 \%$ of $\mathrm{NH}_{4}-\mathrm{N}$ ), while acting as a net source of dissolved organic $\mathrm{N}$. The dominance of $\mathrm{NH}_{4}-\mathrm{N}$ over $\mathrm{NO}_{3}-\mathrm{N}$ suggests that denitrification rates are high enough to remove available $\mathrm{NO}_{3}^{-}$and that nitrification could be limited by high acidity or by high organic $\mathrm{C}$ (Davidsson and Stahl 2000). In other work at TLRP, we have found that soil denitrification potential is relatively low compared to other wetlands (Reddy and Delaune 2008, Morse 2010), which suggests that nitrification could be a major determinant of denitrification by limiting $\mathrm{NO}_{3}{ }^{-}$supply. The role of nitrification in controlling denitrification rates in restored wetlands is not frequently discussed when considering the impor- 
TABLE 2. Reported non- $\mathrm{CO}_{2}$ greenhouse gas $(\mathrm{GHG})$ fluxes $\left(\mathrm{N}_{2} \mathrm{O}\right.$ and $\left.\mathrm{CH}_{4}\right)$ and $\mathrm{CO}_{2}$ equivalents for selected freshwater wetlands (WL), forests, and agricultural systems, by approximate latitude and land use (A, agricultural; D, drained; R, restored; U, unmanaged).

\begin{tabular}{|c|c|c|c|c|c|c|}
\hline Source & Ecosystem & Latitude $\left({ }^{\circ}\right)$ & $\begin{array}{l}\text { Land } \\
\text { use }\end{array}$ & $\begin{array}{c}\mathrm{N}_{2} \mathrm{O} \\
\left(\mathrm{kg} \cdot \mathrm{ha}^{-1} \cdot \mathrm{yr}^{-1}\right)\end{array}$ & $\begin{array}{c}\mathrm{CH}_{4} \\
\left(\mathrm{~kg} \cdot \mathrm{ha}^{-1} \cdot \mathrm{yr}^{-1}\right)\end{array}$ & $\begin{array}{c}\mathrm{CO}_{2} \text { equivalents } \\
\left(\mathrm{kg} \cdot \mathrm{ha}^{-1} \cdot \mathrm{yr}^{-1}\right)\end{array}$ \\
\hline Zona et al. (2009) & boreal peatland, tundra & 71 & $\mathrm{D}$ & & $0-175$ & \\
\hline Liikanen et al. (2009) & $\begin{array}{l}\text { temperate marshes, } \\
\text { Baltic Sea }\end{array}$ & 64 & $\mathrm{U}$ & -0.1 to 0.24 & 631 to 883 & 15800 to 22100 \\
\hline $\begin{array}{l}\text { Sovik and Klove } \\
\text { (2007) }\end{array}$ & $\begin{array}{l}\text { temperate constructed } \\
\text { WL, Norway }\end{array}$ & 59 & $\mathrm{R}$ & -2.81 to 631 & -5.84 to 9250 & -984 to 419000 \\
\hline Mander et al. (2008) & $\begin{array}{l}\text { temperate constructed } \\
\text { WL, Estonia }\end{array}$ & 58 & DR & 7.46 to 23.5 & 6.81 to 204 & 2390 to 12100 \\
\hline Dinsmore et al. (2009) & $\begin{array}{l}\text { temperate peat bog, } \\
\text { Scotland }\end{array}$ & 56 & $\mathrm{U}$ & 0.01 & 1.41 & 38.3 \\
\hline $\begin{array}{l}\text { Stadmark and } \\
\text { Leonardson (2005) }\end{array}$ & $\begin{array}{l}\text { temperate constructed } \\
\text { WL, Sweden }\end{array}$ & 55 & $\mathrm{R}$ & 0 & 70.1 to 6310 & 79700 \\
\hline Matson et al. (2009) & boreal forests, Canada & 53 & $\mathrm{U}$ & 0 & -0.63 & -15.8 \\
\hline Hefting et al. (2003) & $\begin{array}{l}\text { temperate riparian } \\
\text { forest, Netherlands }\end{array}$ & 52 & A & 31.43 & $\cdots$ & $\cdots$ \\
\hline Hefting et al. (2003) & $\begin{array}{l}\text { temperate riparian } \\
\text { grass, Netherlands }\end{array}$ & 52 & A & 1.57 to 3.14 & $\cdots$ & $\cdots$ \\
\hline Hendriks et al. (2007) & $\begin{array}{l}\text { temperate peatlands, } \\
\text { Netherlands }\end{array}$ & 52 & $\mathrm{ADR}$ & -13.8 to 13.8 & 145 to 689 & -479 to 21300 \\
\hline Freeman et al. (1993) & $\begin{array}{l}\text { temperate peat } \\
\text { monolith, Wales }\end{array}$ & 51 & $\mathrm{AD}$ & 0.4 to 4.16 & 164 to 2190 & 4230 to 56000 \\
\hline Brumme et al. (1999) & $\begin{array}{l}\text { temperate forested WL, } \\
\text { Germany }\end{array}$ & 50 & $\mathrm{U}$ & 0.19 to 1.04 & $\cdots$ & $\cdots$ \\
\hline Schmidt et al. (1988) & $\begin{array}{l}\text { temperate forests, } \\
\text { Germany }\end{array}$ & 50 & $\mathrm{U}$ & 0.41 to 1.51 & $\cdots$ & $\cdots$ \\
\hline Brumme et al. (1999) & $\begin{array}{l}\text { temperate forest, } \\
\text { Germany }\end{array}$ & 49 & $\mathrm{U}$ & 11.47 & $\cdots$ & $\cdots$ \\
\hline $\begin{array}{l}\text { Butterbach-Bahl et al. } \\
\text { (2002) }\end{array}$ & $\begin{array}{l}\text { temperate forests, } \\
\text { Germany }\end{array}$ & 48 & $\mathrm{U}$ & 1.54 to 10.1 & $\cdots$ & $\cdots$ \\
\hline Oorts et al. (2007) & $\begin{array}{l}\text { temperate croplands, } \\
\text { conventional, corn/ } \\
\text { soy, France }\end{array}$ & 48 & A & 1.02 to 1.49 & $\cdots$ & $\cdots$ \\
\hline Oorts et al. (2007) & $\begin{array}{l}\text { temperate croplands, } \\
\text { no-till, corn/soy, } \\
\text { France }\end{array}$ & 48 & A & 1.26 to 2.89 & $\cdots$ & $\cdots$ \\
\hline Gleason et al. (2009) & $\begin{array}{l}\text { temperate croplands, } \\
\text { North Dakota, USA }\end{array}$ & 47 & $\mathrm{AD}$ & 0.46 to 7.51 & -1.17 to 1310 & 108 to 35100 \\
\hline Gleason et al. (2009) & $\begin{array}{l}\text { temperate wet meadow, } \\
\text { North Dakota, USA }\end{array}$ & 47 & $\mathrm{ADR}$ & 0.17 to 9.46 & -6.18 to 1080 & -103 to 29900 \\
\hline Brumme et al. (1999) & $\begin{array}{l}\text { temperate pine forest, } \\
\text { Wisconsin, USA }\end{array}$ & 44 & $\mathrm{U}$ & 1.56 & $\cdots$ & $\cdots$ \\
\hline $\begin{array}{l}\text { Altor and Mitsch } \\
\text { (2006) }\end{array}$ & $\begin{array}{l}\text { temperate riparian } \\
\text { marshes, Ohio, USA }\end{array}$ & 40 & $\mathrm{R}$ & $\cdots$ & 307 to 934 & $\cdots$ \\
\hline $\begin{array}{l}\text { Altor and Mitsch } \\
\text { (2008) }\end{array}$ & $\begin{array}{l}\text { riparian mesocosms, } \\
\text { Ohio, USA }\end{array}$ & 40 & $\mathrm{R}$ & $\cdots$ & 48.5 to 91.7 & $\cdots$ \\
\hline $\begin{array}{l}\text { Hernandez and Mitsch } \\
(2006)\end{array}$ & $\begin{array}{l}\text { riparian marshes, Ohio, } \\
\text { USA }\end{array}$ & 40 & $\mathrm{R}$ & 0.31 to 0.95 & $\cdots$ & $\cdots$ \\
\hline Mosier et al. (1986) & $\begin{array}{l}\text { croplands, barley/corn, } \\
\text { Colorado, USA }\end{array}$ & 39 & A & 34.4 to 103 & $\cdots$ & $\cdots$ \\
\hline Rolston et al. (1978) & $\begin{array}{l}\text { croplands, ryegrass, } \\
\text { California, USA }\end{array}$ & 38 & A & 57.4 to 1840 & $\cdots$ & $\cdots$ \\
\hline This study & $\begin{array}{l}\text { cropland, corn/soy, } \\
\text { North Carolina, USA }\end{array}$ & 36 & $\mathrm{AD}$ & 3.0 to 139 & -0.65 to 28.0 & 910 to 42100 \\
\hline This study & $\begin{array}{l}\text { forested wetlands, } \\
\quad \text { North Carolina, USA }\end{array}$ & 36 & $\mathrm{U}$ & -1.1 to 14.1 & -6.9 to 194 & -500 to 9050 \\
\hline This study & $\begin{array}{l}\text { restored agricultural } \\
\text { wetland, North } \\
\text { Carolina, USA }\end{array}$ & 36 & $\mathrm{ADR}$ & -0.2 to 44 & 0.7 to 197 & -42.1 to 18000 \\
\hline Pulliam (1993) & $\begin{array}{c}\text { forested wetland, } \\
\text { Georgia, USA }\end{array}$ & 32 & $\mathrm{U}$ & $\ldots$ & 228 & $\cdots$ \\
\hline Zou et al. (2005) & $\begin{array}{l}\text { subtropical rice paddies, } \\
\text { China }\end{array}$ & 32 & $\mathrm{AD}$ & 0.17 to 51.4 & 124 to 907 & 3140 to 38000 \\
\hline Xiong et al. (2007) & $\begin{array}{l}\text { subtropical rice paddies, } \\
\text { China }\end{array}$ & 31 & $\mathrm{AD}$ & 16.9 to 21.2 & 0 to 11100 & 5030 to 284000 \\
\hline Yu et al. 2008) & $\begin{array}{l}\text { subtropical forested } \\
\text { wetland, Louisiana, } \\
\text { USA }\end{array}$ & 31 & $\mathrm{U}$ & -2.19 to 173 & -2.63 to 249 & -718 to 114000 \\
\hline Liu et al. (2008) & $\begin{array}{l}\text { subtropical plantations, } \\
\text { China }\end{array}$ & 22 & A & 4.76 to 13.6 & -3.48 to -3.43 & $\cdots$ \\
\hline
\end{tabular}


TABLE 2. Continued.

\begin{tabular}{|c|c|c|c|c|c|c|}
\hline Source & Ecosystem & Latitude $\left(^{\circ}\right)$ & $\begin{array}{c}\text { Land } \\
\text { use }\end{array}$ & $\begin{array}{c}\mathrm{N}_{2} \mathrm{O} \\
\left(\mathrm{kg} \cdot \mathrm{ha}^{-1} \cdot \mathrm{yr}^{-1}\right)\end{array}$ & $\begin{array}{c}\mathrm{CH}_{4} \\
\left(\mathrm{~kg} \cdot \mathrm{ha}^{-1} \cdot \mathrm{yr}^{-1}\right)\end{array}$ & $\begin{array}{c}\mathrm{CO}_{2} \text { equivalents } \\
\left(\mathrm{kg} \cdot \mathrm{ha}^{-1} \cdot \mathrm{yr}^{-1}\right)\end{array}$ \\
\hline Brumme et al. (1999) & $\begin{array}{l}\text { tropical wet forest, } \\
\text { Brazil }\end{array}$ & 10 & $\mathrm{U}$ & 9.27 & $\ldots$ & 1330 to 3960 \\
\hline Brumme et al. (1999) & $\begin{array}{l}\text { tropical wet forest, } \\
\text { Brazil }\end{array}$ & -3 & $\mathrm{U}$ & 2.99 & $\cdots$ & $\cdots$ \\
\hline Bartlett et al. (1988) & $\begin{array}{l}\text { tropical forested WL, } \\
\text { Amazon }\end{array}$ & -3 & $\mathrm{U}$ & $\cdots$ & 603 to 799 & $\cdots$ \\
\hline $\begin{array}{l}\text { Livingston et al. } \\
\text { (1988) }\end{array}$ & $\begin{array}{l}\text { tropical forests, } \\
\text { Amazon }\end{array}$ & -10 & $\mathrm{U}$ & 1.79 & $\cdots$ & $\cdots$ \\
\hline Brumme et al. (1999) & $\begin{array}{l}\text { tropical wet forest, } \\
\text { Costa Rica }\end{array}$ & -15 & $\mathrm{U}$ & 3.82 & $\cdots$ & $\cdots$ \\
\hline Weier et al. (1996) & $\begin{array}{l}\text { croplands, sugarcane, } \\
\text { Australia }\end{array}$ & -19 & A & 34.4 to 516 & $\cdots$ & $\cdots$ \\
\hline
\end{tabular}

Note: Ellipses indicate that no data was available.

tance of denitrification to wetland restoration and ecosystem services (e.g., Schlesinger et al. 2006, Verhoeven et al. 2006), yet it is likely to be an important constraint on the ability of acidic wetlands to provide water quality benefits and an important determinant of $\mathrm{N}_{2} \mathrm{O}$ fluxes (Reddy and Patrick 1984).

\section{Conclusions}

Over the two years of our study, when considering the net radiative balance of the three GHGs, we found that $\mathrm{CO}_{2}$ was the largest component (66-100\% of total GHGs) and did not differ between land uses in our study. This is an important reminder that soil respiration must be accounted for when drawing conclusions about the GHG consequences of converting wetlands to farmlands or vice-versa (contra Huang et al. 2010). If we exclude soil $\mathrm{CO}_{2}$ flux, the wet portions of the restored wetland were greater sources of GHG, but not higher than the reference sites, while drier and intermittent areas within RW were significantly lower. Restoring wetland hydrology to TLRP has led to significant $\mathrm{NO}_{3}$ retention or removal (Ardón et al. 2010b), but does not appear to have significantly increased GHG emissions (contra Verhoeven et al. 2006). This conclusion has been reached in a few other studies in constructed wetlands in Estonia (Mander et al. 2005) and restored prairie wetlands in South Dakota (Gleason et al. 2009). The current study, by presenting data for acidic coastal freshwater wetlands in a humid-subtropical climate, provides a regional and biogeochemical perspective that has not been presented to date.

\section{ACKNOWLEDGMENTS}

We thank R. Bier and M. Burke-Scoll for help in the field and the laboratory. We thank Curt Richardson and the Wetlands Center for their contributions. This research was supported by a private gift from Great Dismal Swamp Mitigation Bank in support of basic research, grant 70233 from North Carolina's Water Resource Research Institute, a grant from the NC Department of the Environment and Natural Resources, and a grant to E. S. Bernhardt from the U.S. Department of Energy's Office of Science (BER) through the Coastal Center of the National Institute for Climatic Change Research at Tulane University. J. L. Morse was supported by a U.S. Environmental Protection Agency Science to Achieve Results (STAR) Fellowship (FP916599), and M. Ardón was supported by NSF DBI-085576.

\section{Literature Cited}

Altor, A. E., and W. J. Mitsch. 2006. Methane flux from created riparian marshes: Relationship to intermittent versus continuous inundation and emergent macrophytes. Ecological Engineering 28:224-234.

Altor, A. E., and W. J. Mitsch. 2008. Methane and carbon dioxide dynamics in wetland mesocosms: effects of hydrology and soils. Ecological Applications 18:1307-1320.

Ardón, M., S. Montanari, J. L. Morse, M. W. Doyle, and E. S. Bernhardt. 2010a. Phosphorus export from a restored wetland ecosystem in response to natural and experimental hydrologic fluctuations. Journal of Geophysical ResearchBiogeosciences 115:G04031.

Ardón, M., J. L. Morse, M. W. Doyle, and E. S. Bernhardt. $2010 \mathrm{~b}$. The water quality consequences of restoring wetland hydrology to a large agricultural watershed in the southeastern coastal plain. Ecosystems 13:1060-1078.

Bartlett, K. B., P. M. Crill, D. I. Sebacher, R. C. Harriss, J. O. Wilson, and J. M. Melack. 1988. Methane flux from the central Amazonian floodplain. Journal of Geophysical Research-Atmospheres 93:1571-1582.

Bridgham, S. D., J. P. Megonigal, J. K. Keller, N. B. Bliss, and C. Trettin. 2006. The carbon balance of North American wetlands. Wetlands 26:889-916.

Bridgham, S. D., and C. J. Richardson. 1992. Mechanisms controlling soil respiration $\left(\mathrm{CO}_{2}\right.$ and $\left.\mathrm{CH}_{4}\right)$ in southern peatlands. Soil Biology and Biochemistry 24:1089-1099.

Brinson, M. M., and R. Rheinhardt. 1996. The role of reference wetlands in functional assessment and mitigation. Ecological Applications 6:69-76.

Brumme, R., W. Borken, and S. Finke. 1999. Hierarchical control on nitrous oxide emission in forest ecosystems. Global Biogeochemical Cycles 13:1137-1148.

Butterbach-Bahl, K., L. Breuer, R. Gasche, G. Willibald, and H. Papen. 2002. Exchange of trace gases between soils and the atmosphere in Scots pine forest ecosystems of the northeastern German lowlands 1. Fluxes of $\mathrm{N}_{2} \mathrm{O}, \mathrm{NO} / \mathrm{NO}_{2}$ and $\mathrm{CH}_{4}$ at forest sites with different $\mathrm{N}$-deposition. Forest Ecology and Management 167:123-134.

Carter, L. J. 1975. Agriculture-new frontier in coastal North Carolina. Science 189:271-275.

Conrad, R., and W. Seiler. 1988. Influence of the surface microlayer on the flux of nonconservative trace gases $(\mathrm{CO}$, $\mathrm{H}_{2}, \mathrm{CH}_{4}, \mathrm{~N}_{2} \mathrm{O}$ ) across the ocean-atmosphere interface. Journal of Atmospheric Chemistry 6:83-94.

Dahl, T. E. 1990. Wetlands losses in the United States: 1780's to 1980 's. U.S. Department of the Interior, Fish and Wildlife Service, Washington, D.C., USA. 
Davidson, E. A., M. Keller, H. E. Erickson, L. V. Verchot, and E. Veldkamp. 2000. Testing a conceptual model of soil emissions of nitrous and nitric oxides. Bioscience 50:667-680.

Davidsson, T. E., and M. Stahl. 2000. The influence of organic carbon on nitrogen transformations in five wetland soils. Soil Science Society of America Journal 64:1129-1136.

De Boer, W., and G. A. Kowalchuk. 2001. Nitrification in acid soils: micro-organisms and mechanisms. Soil Biology and Biochemistry 33:853-866.

Dinsmore, K. J., U. M. Skiba, M. F. Billett, R. M. Rees, and J. Drewer. 2009. Spatial and temporal variability in $\mathrm{CH}_{4}$ and $\mathrm{N}_{2} \mathrm{O}$ fluxes from a Scottish ombrotrophic peatland: Implications for modelling and up-scaling. Soil Biology and Biochemistry 41:1315-1323.

Eberling, B., H. H. Christansen, and B. U. Hansen. 2010. High nitrous oxide production from thawing permafrost. Nature Geoscience 3:332-336.

Fogg, P. G. T., and J. Sangster. 2003. Chemicals in the atmosphere: solubility, sources, and reactivity. John Wiley and Sons, West Sussex, UK.

Forster, P., et al. 2007. Changes in atmospheric constituents and in radiative forcing. In S. Solomon, D. Qin, M. Manning, Z. Chen, M. Marquis, K. B. Averyt, M. Tignor, and H. L. Miller, editors. Climate change 2007: the physical science basis. Contribution of Working Group I to the Fourth Assessment Report of the Intergovernmental Panel on Climate Change. Cambridge University Press, Cambridge, UK.

Freeman, C., M. A. Lock, and B. Reynolds. 1993. Fluxes of $\mathrm{CO}_{2}, \mathrm{CH}_{4}$, and $\mathrm{N}_{2} \mathrm{O}$ from a Welsh peatland following simulation of water-table draw-down - potential feedback to climatic change. Biogeochemistry 19:51-60.

Gleason, R. A., B. A. Tangen, B. A. Browne, and N. H. Euliss. 2009. Greenhouse gas flux from cropland and restored wetlands in the Prairie Pothole Region. Soil Biology and Biochemistry 41:2501-2507.

Good, P. 2000. Permutation tests. Springer, New York, New York, USA.

Groffman, P. M., J. P. Hardy, M. C. Fish, T. J. Fahey, and C. T. Driscoll. 2009. Climate variation and soil carbon and nitrogen cycling processes in a northern hardwood forest. Ecosystems 12:927-943.

Harrell, F. E., Jr. 2009. Hmisc: Harrell miscellaneous. R package version 3.7-0. R Foundation for Statistical Computing, Vienna, Austria. http://cran.r-project.org/web/ packages/Hmisc/index.html

Hefting, M. M., R. Bobbink, and H. de Caluwe. 2003. Nitrous oxide emission and denitrification in chronically nitrateloaded riparian buffer zones. Journal of Environmental Quality 32:1194-1203.

Heimlich, R. E., K. D. Wiebe, R. Claassen, D. Gadsby, and R. M. House, 1998. Wetlands and agriculture: private interests and public benefits. Agricultural economic report. USDA, Washington, D.C., USA.

Hendershot, W. H., H. Lalande, and M. I. Duquette. 1993. Soil reaction and exchangeable acidity. Pages 141-143 in M. R. Carter, editor. Soil sampling and methods of analysis. Lewis Publishers, Boca Raton, Florida, USA.

Hendriks, D. M. D., J. van Huissteden, A. J. Dolman, and M. K. van der Molen. 2007. The full greenhouse gas balance of an abandoned peat meadow. Biogeosciences 4:411-424.

Hernandez, M. E., and W. J. Mitsch. 2006. Influence of hydrologic pulses, flooding frequency, and vegetation on nitrous oxide emissions from created riparian marshes. Wetlands 26:862-877.

Hothorn, T., K. Hornick, M. A. van de Wiel, and A. Zeileis. 2008. Implementing a class of permutation tests: the coin package. Journal of Statistical Software 28:1-23.

Huang, Y., W. Sun, W. Zhang, Y. Yu, Y. Su, and C. Song. 2010. Marshland conversion to cropland in northeast China from 1950 to 2000 reduced the greenhouse effect. Global Change Biology 16:680-695.

Hudson, F. 2004. Standard Operating Procedure: sample preparation and calculations for dissolved gas analysis in water samples using a GC headspace equilibration technique. U.S. Environmental Protection Agency, Washington, D.C., USA.

Hume, N. P., M. S. Fleming, and A. J. Horne. 2002. Denitrification potential and carbon quality of four aquatic plants in wetland microcosms. Soil Science Society of America Journal 66:1706-1712.

Hunt, P. G., T. A. Matheny, and K. S. Ro. 2007. Nitrous oxide accumulation in soils from riparian buffers of a coastal plain watershed-carbon/nitrogen ratio control. Journal of Environmental Quality 36:1368-1376.

Jackson, R. B., E. G. Jobbagy, R. Avissar, S. B. Roy, D. J. Barrett, C. W. Cook, K. A. Farley, D. C. le Maitre, B. A. McCarl, and B. C. Murray. 2005. Trading water for carbon with biological carbon sequestration. Science 310:1944-1947. Jenkins, W. A., B. C. Murray, R. A. Kramer, and S. P. Faulkner. 2010. Valuing ecosystem services from wetlands restoration in the Mississippi Alluvial Valley. Ecological Economics 69:1051-1061.

Johnston, C. A. 1991. Sediment and nutrient retention by freshwater wetlands: effects on surface water quality. Critical Reviews in Environmental Control 21:491-565.

Kelker, D., and J. Chanton. 1997. The effect of clipping on methane emissions from Carex. Biogeochemistry 39:37-44.

Laanbroek, H. J. 2010. Methane emissions from natural wetlands: interplay between emergent macrophytes and soil microbial processes. A mini-review. Annals of Botany 105:141-153.

Le Mer, J., and P. Roger. 2001. Production, oxidation, emission and consumption of methane by soils: A review. European Journal of Soil Biology 37:25-50.

Levins, R., and C. Lopez. 1999. Toward an eco-social view of health. International Journal of Health Services 29:261-293.

Liikanen, A., H. Silvennoinen, A. Karvo, P. Rantakokko, and P. J. Martikainen. 2009. Methane and nitrous oxide fluxes in two coastal wetlands in the northeastern Gulf of Bothnia, Baltic Sea. Boreal Environment Research 14:351-368.

Liu, H., P. Zhao, P. Lu, Y. S. Wang, Y. B. Lin, and X. Q. Rao. 2008. Greenhouse gas fluxes from soils of different land-use types in a hilly area of South China. Agriculture Ecosystems and Environment 124:125-135.

Liu, L. L., and T. L. Greaver. 2009. A review of nitrogen enrichment effects on three biogenic GHGs: the $\mathrm{CO}_{2}$ sink may be largely offset by stimulated $\mathrm{N}_{2} \mathrm{O}$ and $\mathrm{CH}_{4}$ emission. Ecology Letters 12:1103-1117.

Livingston, G. P., and G. L. Hutchinson. 1995. Enclosurebased measurement of trace-gas exchange: applications and sources of error. Pages 14-51 in P. A. Matson, R. C. Harriss, editor. Biogenic trace gases: measuring emissions from soil and water. Blackwell Science, Cambridge, Massachusetts, USA.

Livingston, G. P., P. M. Vitousek, and P. A. Matson. 1988. Nitrous-oxide flux and nitrogen transformations across a landscape gradient in Amazonia. Journal of Geophysical Research-Atmospheres 93:1593-1599.

MacIntyre, S., R. Wanninkhof, and J. P. Chanton. 1995. Tracegas exchange across the air-water interface in freshwater and coastal marine environments. Pages 52-97 in P. A. Matson, R. C. Harriss, editors. Biogenic trace gases: measuring emissions from soil and water. Blackwell Science, Cambridge, Massachusetts, USA.

Mander, U., K. Lohmus, S. Teiter, T. Mauring, K. Nurk, and J. Augustin. 2008. Gaseous fluxes in the nitrogen and carbon budgets of subsurface flow constructed wetlands. Science of the Total Environment 404:343-353.

Mander, U., S. Teiter, and J. Augustin. 2005. Emission of greenhouse gases from constructed wetlands for wastewater 
treatment and from riparian buffer zones. Water Science and Technology 52:167-176.

Matson, A., D. Pennock, and A. Bedard-Haughn. 2009. Methane and nitrous oxide emissions from mature forest stands in the boreal forest, Saskatchewan, Canada. Forest Ecology and Management 258:1073-1083.

McLain, J. E. T., T. B. Kepler, and D. M. Ahmann. 2002. Belowground factors mediating changes in methane consumption in a forest soil under elevated $\mathrm{CO}_{2}$. Global Biogeochemical Cycles 16:1050.

Megonigal, J. P., M. E. Hines, and P. T. Visscher. 2004. Anaerobic metabolism: linkages to trace gases and aerobic processes. Pages 317-424 in W. H. Schlesinger, editor. Treatise on geochemistry: biogeochemistry. Elsevier-Pergamon, Oxford, UK.

Millennium Ecosystem Assessment. 2005. Ecosystems and human well-being: wetlands and water. World Resources Institute, Washington, D.C., USA.

Mitsch, W. 2005. Applying science to conservation and restoration of the world's wetlands. Water Science and Technology 51:13-26.

Mitsch, W. J., J. W. Day, L. Zhang, and R. R. Lane. 2005. Nitrate-nitrogen retention in wetlands in the Mississippi River Basin. Ecological Engineering 24:267-278.

Morse, J. L. 2010. Farm fields to wetlands: biogeochemical consequences of re-flooding in coastal plain agricultural lands. Dissertation. Duke University, Durham, North Carolina, USA.

Mosier, A. R., W. D. Guenzi, and E. E. Schweizer. 1986. Soil losses of dinitrogen and nitrous-oxide from irrigated crops in northeastern Colorado. Soil Science Society of America Journal 50:344-348.

Mosier, A., C. Kroeze, C. Nevison, O. Oenema, S. Seitzinger, and O. van Cleemput. 1998. Closing the global $\mathrm{N}_{2} \mathrm{O}$ budget: nitrous oxide emissions through the agricultural nitrogen cycle: OECD/IPCC/IEA phase II development of IPCC guidelines for national greenhouse gas inventory methodology. Nutrient Cycling in Agroecosystems 52:225-248.

National Agricultural Statistics Service. 1999. 1997 Census of Agriculture. USDA, Washington, D.C., USA.

National Research Council. 2001. Compensating for wetland losses under the Clean Water Act. National Academy Press, Washington, D.C., USA.

Natural Resources Conservation Service. 2009. Soil Survey Geographic (SSURGO) database for Tyrrell County, North Carolina. USDA, Natural Resources Conservation Service, Fort Worth, Texas, USA.

Needham, R. 2006. Implementation plan for agricultural restoration at Timberlake Farms. Needham Environmental, Wilmington, North Carolina, USA.

Neely, H. 2008. Restoring farmland to wetlands: the potential for carbon credits in eastern North Carolina. Thesis. Duke University, Durham, North Carolina, USA.

Neubauer, S. C., K. Givler, S. Valentine, and J. P. Megonigal. 2005. Seasonal patterns and plant-mediated controls of subsurface wetland and biogeochemistry. Ecology 86:33343344.

Odum, E. P. 1969. The strategy of ecosystem development. Science 164:262-270.

Oorts, K., R. Merckx, E. Grehan, J. Labreuche, and B. Nicolardot. 2007. Determinants of annual fluxes of $\mathrm{CO}_{2}$ and $\mathrm{N}_{2} \mathrm{O}$ in long-term no-tillage and conventional tillage systems in northern France. Soil and Tillage Research 95:133-148.

Orr, C. H., E. H. Stanley, K. A. Wilson, and J. C. Finlay. 2007. Effects of restoration and reflooding on soil denitrification in a leveed midwestern floodplain. Ecological Applications 17:2365-2376.

Papen, H., and K. Butterbach-Bahl. 1999. A 3-year continuous record of nitrogen trace gas fluxes from untreated and limed soil of a N-saturated spruce and beech forest ecosystem in
Germany: 1. $\mathrm{N}_{2} \mathrm{O}$ emissions. Journal of Geophysical Research-Atmospheres 104:18487-18503.

Peng, Y., S. C. Thomas, and D. Tian. 2008. Forest management and soil respiration: implications for carbon sequestration. Environmental Reviews 16:93-111.

Poe, A. C., M. F. Piehler, S. P. Thompson, and H. W. Paerl. 2003. Denitrification in a constructed wetland receiving agricultural runoff. Wetlands 23:817-826.

Poulter, B., and P. N. Halpin. 2008. Raster modelling of coastal flooding from sea-level rise. International Journal of Geographical Information Science 22:167-182.

Pregitzer, K. S., and E. S. Euskirchen. 2004. Carbon cycling and storage in world forests: biome patterns related to forest age. Global Change Biology 10:2052-2077.

Pulliam, W. M. 1993. Carbon dioxide and methane exports from a southeastern floodplain swamp. Ecological Monographs 63:29-53.

R Development Core Team. 2009. R: A language and environment for statistical computing. R Foundation for Statistical Computing, Vienna, Austria.

Raich, J. W., and W. H. Schlesinger. 1992. The global carbondioxide flux in soil respiration and its relationship to vegetation and climate. Tellus Series B-Chemical and Physical Meteorology 44:81-99.

Reddy, K. R., and R. D. Delaune. 2008. Biogeochemistry of wetlands: science and applications. CRC Press, New York, New York, USA.

Reddy, K. R., and W. H. Patrick. 1984. Nitrogen transformations and loss in flooded soils and sediments. Critical Reviews in Environmental Control. 13:273-309.

Richardson, C. J. 1983. Pocosins: Vanishing wastelands or valuable wetlands? BioScience 33:626-633.

Richardson, C. J. 1985. Mechanisms controlling phosphorus retention capacity in freshwater wetlands. Science 228:14241427.

Richardson, C. J. 2003. Pocosins: Hydrologically isolated or integrated wetlands on the landscape? Wetlands 23:563-576.

Richardson, C. J., and E. J. McCarthy. 1994. Effect of landdevelopment and forest management on hydrologic response in southeastern coastal wetlands: a review. Wetlands 14:56-71.

Ripley, B., and M. Lapsley. 2009. RODBC: ODBC database access. R package version 1.3-1. R Foundation for Statistical Computing, Vienna, Austria. http://cran.r-project.org/web/ packages/Hmisc/index.html

Rolston, D. E., D. L. Hoffman, and D. W. Toy. 1978. Field measurement of denitrification. 1. flux of $\mathrm{N}_{2}$ and $\mathrm{N}_{2} \mathrm{O}$. Soil Science Society of America Journal 42:863-869.

Rönnberg, C., and E. Bonsdorff. 2004. Baltic Sea eutrophication: area-specific ecological consequences. Hydrobiologia 514:227-241.

Schlesinger, W. H. 1997. Biogeochemistry: an analysis of global change. Academic Press, New York, New York, USA.

Schlesinger, W. H. 2009. On the fate of anthropogenic nitrogen. Proceedings of the National Academy of Sciences USA 106:203-208.

Schlesinger, W. H., K. H. Reckhow, and E. S. Bernhardt. 2006. Global change: The nitrogen cycle and rivers. Water Resources Research 42:W03S06.

Seitzinger, S. P. 1988. Denitrification in fresh-water and coastal marine ecosystems: ecological and geochemical significance. Limnology and Oceanography 33:702-724.

Shimadzu Scientific Instruments. 2004. GCSolution software. Version 2.3. Shimadzu Scientific Instruments, Columbia, Maryland, USA.

Smith, J. E., L. S. Heath, K. E. Skog, and R. A. Birdsey. 2006. Methods for calculating forest ecosystem and harvested carbon with standard estimates for forest types of the United States. General Technical Report NE-343. Northeastern Research Station, USDA Forest Service, Newtown Square, Pennsylvania, USA. 
Sovik, A. K., and B. Klove. 2007. Emission of $\mathrm{N}_{2} \mathrm{O}$ and $\mathrm{CH}_{4}$ from a constructed wetland in southeastern Norway. Science of the Total Environment 380:28-37.

Stadmark, J., and L. Leonardson. 2005. Emissions of greenhouse gases from ponds constructed for nitrogen removal. Ecological Engineering 25:542-551.

Turner, R. E., N. N. Rabalais, and D. Justic, 2008. Gulf of Mexico hypoxia: alternate states and a legacy. Environmental Science and Technology 42:2323-2327.

Tyree, M. C., J. R. Seiler, W. M. Aust, D. A. Sampson, and T. R. Fox. 2006. Long-term effects of site preparation and fertilization on total soil $\mathrm{CO}_{2}$ efflux and heterotrophic respiration in a 33-year-old Pinus taeda L. plantation on the wet flats of the Virginia Lower Coastal Plain. Forest Ecology and Management 234:363-369.

U.S. Army Corps of Engineers. 1997. Umbrella memorandum of agreement between bank sponsors, et. al. to establish a procedure for compensation for wetland habitat losses in the historic watershed of the Great Dismal Swamp in the Great Dismal Swamp Restoration Bank and for the development and use of such bank. Legal document number 6099649.3. U.S. Army Corps of Engineers, Washington Regulatory Field Office, Washington, North Carolina, USA.

Vepraskas, M. J., and S. P. Faulkner. 2001. Redox chemistry of hydric soils. Page 417 in J. L. Richardson, and M. J. Vepraskas, editors. Wetland soils: genesis, hydrology, landscapes, and classification. CRC Press, Boca Raton, Florida, USA.

Verhoeven, J. T. A., B. Arheimer, C. Q. Yin, and M. M. Hefting. 2006. Regional and global concerns over wetlands and water quality. Trends in Ecology and Evolution 21:96103.

Wagner, K. I., S. K. Gallagher, M. Hayes, B. A. Lawrence, and J. B. Zedler. 2008. Wetland Restoration in the new millennium: do research efforts match opportunities? Restoration Ecology 16:367-372.

Weier, K. L., C. W. McEwan, I. Vallis, V. R. Catchpoole, and R. J. Myers. 1996. Potential for biological denitrification of fertilizer nitrogen in sugarcane soils. Australian Journal of Agricultural Research 47:A67-A79.
Whiting, G. J., and J. P. Chanton. 2001. Greenhouse carbon balance of wetlands: methane emission versus carbon sequestration. Tellus B 53:521-528.

Wilcock, R., S. Elliott, N. Hudson, S. Parkyn, and J. Quinn. 2008. Climate change mitigation for agriculture: water quality benefits and costs. Water Science and Technology 58:2093-2099.

Xiong, Z. Q., G. X. Xing, and Z. L. Zhu. 2007. Nitrous oxide and methane emissions as affected by water, soil and nitrogen. Pedosphere 17:146-155.

Yates, T. T., B. C. Si, R. E. Farrell, and D. J. Pennock. 2006. Probability distribution and spatial dependence of nitrous oxide emission: Temporal change in hummocky terrain. Soil Science Society of America Journal 70:753-762.

Yu, K. W., S. P. Faulkner, and M. J. Baldwin. 2008. Effect of hydrological conditions on nitrous oxide, methane, and carbon dioxide dynamics in a bottomland hardwood forest and its implication for soil carbon sequestration. Global Change Biology 14:798-812.

Zedler, J. B. 2000. Progress in wetland restoration ecology. Trends in Ecology and Evolution 15:402-407.

Zedler, J. B. 2003. Wetlands at your service: reducing impacts of agriculture at the watershed scale. Frontiers in Ecology and the Environment 1:65-72.

Zedler, J. B., and J. C. Callaway. 1999. Tracking wetland restoration: do mitigation sites follow desired trajectories? Restoration Ecology 7:69-73.

Zedler, J. B., and S. Kercher. 2005. Wetland resources: status, trends, ecosystem services, and restorability. Annual Review of Environment and Resources 30:39-74.

Zona, D., W. C. Oechel, J. Kochendorfer, K. T. Paw U, A. N. Salyuk, P. C. Olivas, S. F. Oberbauer, and D. A. Lipson. 2009. Methane fluxes during the initiation of a large-scale water table manipulation experiment in the Alaskan Arctic tundra. Global Biogeochemical Cycles 23:GB2013.

Zou, J. W., Y. Huang, J. Y. Jiang, X. H. Zheng, and R. L. Sass. 2005. A 3-year field measurement of methane and nitrous oxide emissions from rice paddies in China: Effects of water regime, crop residue, and fertilizer application. Global Biogeochemical Cycles 19: GB2021.

\section{Supplemental Material}

\section{Appendix}

Tables summarizing greenhouse gas flux statistics and cumulative annual fluxes for each study site from July 2007 to June 2009 (Ecological Archives A022-017-A1). 